\title{
Effects of Disturbance on Sandy Coastal Ecosystems of N-Adriatic Coasts (Italy)
}

\author{
Gabriella Buffa, Edy Fantinato and Leonardo Pizzo
}

Additional information is available at the end of the chapter

http://dx.doi.org/10.5772/47480

\section{Introduction}

Due to human driving forces, many terrestrial habitats are undergoing striking modifications, destruction and fragmentation at an increasing and historically unprecedented rate (Sala et al., 2000), drawing attention to ecosystems' resilience as a necessary condition for both biodiversity conservation and sustainable development (McLeod et al., 2005).

Among the most endangered and threatened ecosystems worldwide, there are seashore, coastal sand dunes and nearby wet infradunal downs which are facing escalating anthropogenic pressures (Defeo et al., 2009), chiefly from coastal development, direct human use, mainly associated with recreation, and sea level rise.

All coastal European Countries, and particularly those of the Mediterranean Basin (Curr et al., 2000; European Environment Agency [EEA], 1999), suffer from the loss and degradation of sand dune landscape which are leading to a dramatic biodiversity loss, caused by the alteration and disappearance of many habitats and the rarefaction and/or local extinction of the most typical and extremely specialized native species, sometimes replaced with alien species.

Coastal dune systems make up $20 \%$ of the area occupied by the world's coastal landscapes (van der Maarel, 2003) and contain diverse and productive habitats important for human settlements, development and local subsistence (Schlacher et al., 2008). According to data reported by the United Nations Conference on Environment and Development [UNCED] (1992), about half of the world's population lives within $60 \mathrm{~km}$ of the shoreline, and it is likely to rise to three quarters by the year 2020. Population increase, united with economic progress and development, and the growing demands for spare time opportunities represent the eventual drivers of escalating pressures on sandy beaches (Dugan \& Hubbard, 2010). Particularly coast-bound tourism, which became a mass phenomenon after World 
War II, is now considered the primary cause of degradation of coastal dunes (Acosta et al., 2000). Among European holidaymakers more than $60 \%$ prefer the coast (European Community [EC], 1998) and even more people use sandy beaches which attract the greatest percentage of tourists every year (Davenport \& Davenport, 2006; Schlacher et al., 2007). Rapid growth of human populations on the coast is then expected to further influence beaches and coastal sandy ecosystems with effects on biodiversity, community composition and ecological function (Defeo et al., 2009; Dugan \& Hubbard, 2010).

As for the Italian coastline, more than $3000 \mathrm{~km}$ are represented by sand dune systems, which maintained well preserved morphological, hydrological and naturalistic features until the nineteenth century (Garbari, 1984). From the twentieth century on, they have been suffering from a strong intensification of human activities that mainly include forestry, agriculture, fisheries and aquaculture, transport and tourism, with consequent urbanization, trampling and beach cleaning. During the last century, a loss of about $80 \%$ of dune systems has been calculated for the Mediterranean area as a result of increasing urbanization (EEA, 1995).

Similarly, from 1950 onward, in the N-Adriatic region large stretches of coastal seashores, foredunes and infradunal downs have been fragmented by housing and resort development, road construction and coastal armoring, and the remaining sites suffer from increasing erosion, reduction in sand supply, alteration of geomorphic processes and heavy human use in the form of trampling, mechanical grooming and berm building (Nordstrom et al., 2009).

Coastal dune systems are typical transitional ecosystems, linked both to marine environment and terrestrial river basins, usually extending, narrow and long, along the coastline (Acosta et al., 2007), where environmental factors deeply influence their size, shape and boundaries. Like other ecotones, they exhibit a sharp gradient both in biotic and environmental factors, mainly related to substrate coherence and salinity, wind, salt spray and wave regime, which differ with distance from the water and topographic sheltering (Acosta et al., 2007; Carranza et al., 2008; Lortie \& Cushman, 2007; Nordstrom et al., 2009; Ranwell, 1972). This steep gradient makes them highly dynamic systems deeply influenced by environmental stressors and drivers (Barbour, 1992), but at the same time, as abiotic patterns change within a short distance, it is responsible for the high level of ecological diversity, environmental heterogeneity and for the coexistence of different communities within a relatively limited space (Frederiksen et al., 2006; Martínez et al. 2004; Wilson \& Sykes, 1999). Moreover, coastal dune systems are inhabited by extremely specialized biotic assemblages, rarely shared with adjacent terrestrial ecosystems (Defeo et al., 2009; Kutiel et al., 1999; Schlacher et al., 2008).

Healthy dune ecosystems also provide unique ecological services, such as erosion and salt spray control, storm buffering, water filtration and purification, nutrients mineralisation and recycling, coastal fisheries, functional links between terrestrial and marine environments, provisioning of crucial habitats for endangered species such as birds, as well as cultural services like recreation and education (Barbier et al., 2008; Defeo et al., 2009; Schlacher et al., 2008). 
Furthermore, in Europe, coastal dune habitats are listed in the CORINE biotope classification and some of them are regarded as priority habitats or habitats of community interest in Annex I of the EU Habitat Directive (CE 43/92), recognized as a cornerstone of Europe's nature conservation policy (Feola et al., 2011; Mücher et al., 2004). This status implies they deserve special conservation attention and, as asked by the most recent European legislation, a strategic approach to planning and management in order to achieve sustainable development. As the assessment of the state of ecosystems at a given time and place is at the basis of any planning process for the management and conservation of natural resources, the aim of this study was 1) to provide a comprehensive and up-to-date outline of $\mathrm{N}$-Adriatic sandy coastal landscape; 2) to assess the impacts of anthropogenic disturbance on sandy coastal systems by integrating landscape-level and community-level approaches; 3) verify how habitat configuration is important in supporting landscapes', communities' and plant species' diversity and quality.

\section{Study site}

The investigation was undertaken on the N-Adriatic coast which represents the longest sandy coastal line in Italy. The $100 \mathrm{~km}$ long coastline encompassing the study sites correspond to the Venetian portion of this system, isolated by other areas of sandy coastal plain by the estuaries of large rivers: the Tagliamento river northwards and the BrentaAdige-Po rivers system southwards (Figure 1).

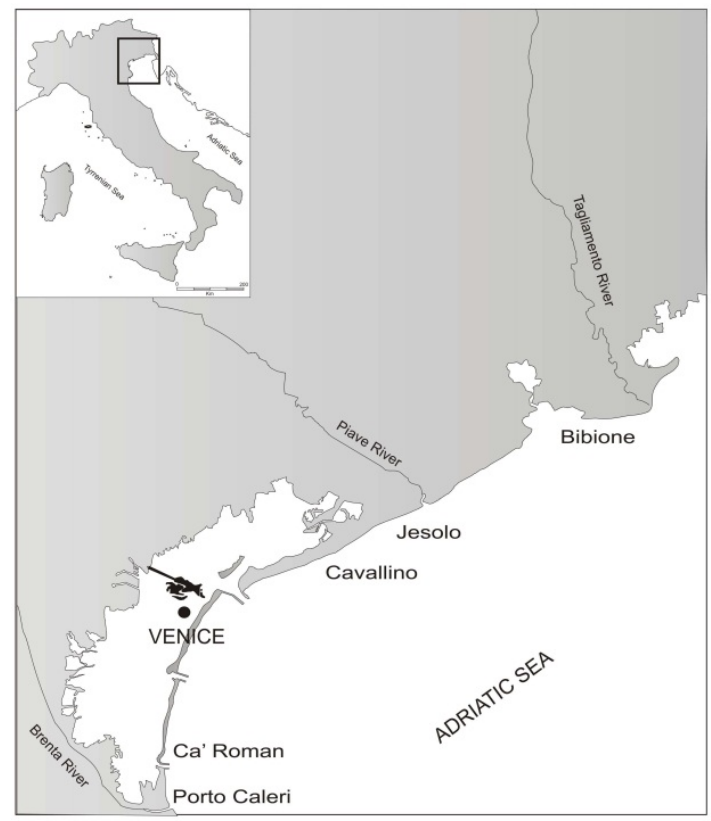

Figure 1. Map of the study site. 
Sites consist of narrow, recent dunes (Holocene), that generally occupy a narrow strip along the seashore, bordered by river mouths and tidal inlets, mostly fixed by docks. The natural forces that shape and influence the dynamic of these sandy coastal systems are basically wind, waves and sea level fluctuations, climate and rivers run-off (Nordstrom et al., 2009). Sediments on the backshore and dunes are similar at all sites and are in the range of fine sand (Bezzi et al., 2009). Carbonate clearly rules the mineralogical composition of sands (especially in the northernmost area) due to the lithology of the catchment areas of corresponding rivers; southwards a slight magmatic component arises (Zunica, 1971). Dominant winds blow from the northeast and east (Bezzi et al., 2009). Annual average wave heights are lower than $0.50 \mathrm{~m}$ (Dal Cin \& Simeoni, 1994); tides are semi-diurnal, with a spring range of about $1.0 \mathrm{~m}$ and a neap range of about $0.20 \mathrm{~m}$ (Polli, 1970); the combination of spring tides, winds and low atmospheric pressure can raise sea level up to $1.60 \mathrm{~m}$.

Climate deserves a closer examination being one of the most characterizing aspects of the site. From a biogeographic point of view, the N-Adriatic seacoast can be included in the Eurosiberian region, Appennine-Balcanic province and Po-Valley subprovince. The mean annual temperature is about $13^{\circ} \mathrm{C}$, with low winter $\left(0.3^{\circ} \mathrm{C}\right)$ and high summer $\left(17.7^{\circ} \mathrm{C}\right)$ values. Mean annual rainfall is $831.5 \mathrm{~mm}$, with maximum precipitation $(89.1 \mathrm{~mm})$ in the spring-autumn season and a minimum $(49.3 \mathrm{~mm})$ in summer. Bioclimatic classification (Rivas-Martinez, 2008) shows a Temperate Oceanic type which allow reference to this area as the only sector of the Mediterranean Basin that does not belong to the Mediterranean climatic Region (Buffa et al., 2005; 2007; Sburlino et al., 2008).

Average annual values of both rainfall and temperature have been increasing since 1992 all along the Venetian coast: mean rainfall shows an increase from $688 \mathrm{~mm}$ in 1992 to the current $976 \mathrm{~mm}(\mathrm{p}<0.05)$; mean temperature has grown from $13.04^{\circ} \mathrm{C}$ to $13.70^{\circ} \mathrm{C}(\mathrm{p}<0.10)$. To evaluate a possible change in climate regime, we compared two time series monitored at the same site (weather station of Cavallino-Venice, located in the central part of the Venetian stretch), comprising the periods between 1961-1990 and 1992-2010 respectively. Although, the two mean annual precipitation do not show a significant difference $\left(\mathrm{P}_{61-90}=809.4 \mathrm{~mm} / \mathrm{P}_{92}\right.$ ${ }_{10}=845.5 \mathrm{~mm} ; \mathrm{df}=47 ; \mathrm{F}=1.73 ; \mathrm{t}=0.71$ ), a seasonal rainfall redistribution has occurred with a shift from an oceanic regime to an equinoctial one that shows two maximum (in spring and autumn) and two minimum. Temperature has also changed: thermic regime remains similar, but with a general shift to higher temperature values; the mean annual temperature increased from $12.7^{\circ} \mathrm{C}$ to the current $13.5^{\circ} \mathrm{C}(\mathrm{p}<0.01)$. Ombrothermic diagrams (Figure 2) allow us to highlight a change of climatic phase which shifted from Low Supratemperate upper subhumid climate to Upper Mesotemperate upper subhumid climate.

Besides the bioclimatic diagnosis, the variation of some bioclimatic indices (reported in Table 1) emphasises an increase of summer aridity, due to the simultaneous increase in temperature and decrease in precipitation, giving evidence to a process of "mediterraneisation" (Fernández-González et al., 2005). Moreover, the general warming lengthened the Period of Plant Activity (i.e., months with mean temperature $>3.5^{\circ} \mathrm{C}$, Rivas-Martinez, 2008) from 10 to 11 months. 

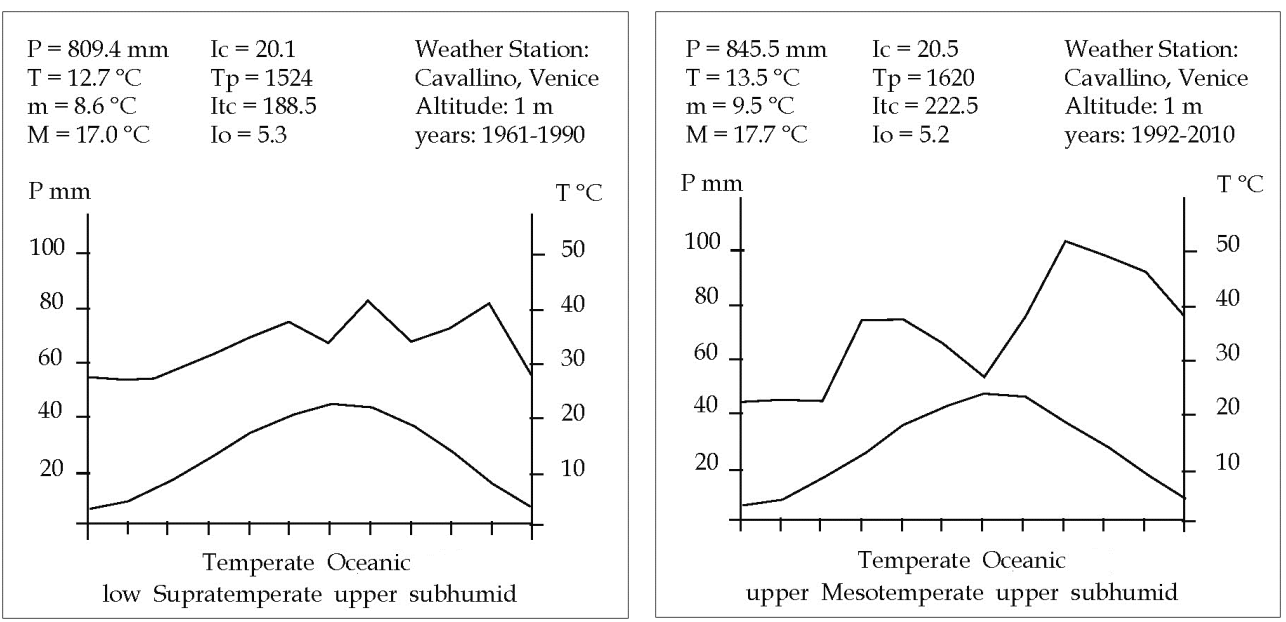

Figure 2. Bioclimatic classification of Cavallino weather station (central part of Venetian coastal stretch), for the period 1961-1990 (left) and 1992-2010 (right). For a detailed description of indices and general theoretical principles see Rivas-Martinez (2008).

\begin{tabular}{lll}
\hline variable & $1961-1990$ & $1992-2010$ \\
\hline $\mathrm{P} \mathrm{mm}$ (annual) & 809.4 & 845.5 \\
$\mathrm{~T}{ }^{\circ} \mathrm{C}$ (annual) & 12.7 & 13.5 \\
$\mathrm{~m}{ }^{\circ} \mathrm{C}$ (annual average of minimum values) & 8.6 & 9.5 \\
$\mathrm{M}^{\circ} \mathrm{C}$ (annual average of maximum values) & 17.0 & 17.7 \\
$\mathrm{Tp}{ }^{\circ} \mathrm{C}$ (positive annual T, with Ti1-12 $>0^{\circ} \mathrm{C}$ ) & 1524 & 1620 \\
$\mathrm{Ts}{ }^{\circ} \mathrm{C}$ (average T of summer three months) & 651 & 686 \\
Ps mm (average P of summer three months) & 227.7 & 195.5 \\
Ios3 (ombrothermic index (Pp/Tp) of summer three months) & 3.5 & 2.8 \\
\hline
\end{tabular}

Table 1. Climatic parameters and bioclimatic indices. For a detailed description of indices and general theoretical principles see Rivas-Martinez (2008).

Many other studies identify the decade 1981-1990 as the onset of climate change in Europe, with a trend starting in the beginning of the 1970s (Werner et al., 2000). In the Veneto Region, this breakpoint is particularly evident for temperature and evapotranspiration: after the change point, in fact, temperatures show a significant increase $\left(+1.5\right.$ and $+0.9{ }^{\circ} \mathrm{C}$ for yearly averages of maximum and minimum temperatures respectively relative to the previous phase) in all seasons and particularly clear in spring, summer and winter for maximum temperatures and in summer for the minimum ones (Chiaudani, 2008).

Human pressures are very high along the entire coastline. Until the 1950s, the Veneto coast was almost entirely fronted by dunes up to $10 \mathrm{~m}$ high (Bezzi \& Fontolan, 2003; Pignatti, 2009), but few of them still survive and beaches generally suffer from the decrease of sediment supplies delivered by rivers, subsidence, and reduction in longshore sediment transport due to interruption by shore-perpendicular structures (Nordstrom et al., 2009). 
To defend shorefront buildings and to provide space for leisure use, from 1950, large beach sectors have been protected, and still are, by different structures, such as groynes (shoreperpendicular constructions that catch sand moving alongshore), jetties and revetments, locally called "murazzi"; some of them, like in Pellestrina, were built by the Venetians in the 18th century and later rebuilt to larger dimensions (Nordstrom et al., 2009).

Most sites are managed by private corporations, through beach concessions by national government, and land behind beaches mostly developed as campsites, resorts, towns and villages; only very few sites ( $\mathrm{Ca}^{\prime}$ Roman, Porto Caleri and partly the "Laguna del Morto" near Eraclea) are still near-natural, undeveloped and underutilized. In 2011, beach summer tourism (from May to September) in the Veneto region numbered more than 25 million visitors. Summer beach tourism is one of the main resources of the region (Bezzi \& Fontolan 2003) and facilities for accommodating people show an average density of about 76.3/100 sqKm. Private beaches management encompasses machine litter cleaning after major storm events and before the tourist season to clean and flatten the sand surface for tourist facilities and during the summer, plant litter and shell fragments are regularly removed and left outside the beaches (Nordstrom et al., 2009).

Therefore, the encroachment of human facilities has severely restricted the space available for natural landforms and vegetation, and environmental gradients have been largely truncated, fragmented or compressed. Scattered here and there, some stretches with high natural value still remain and host high levels of biodiversity. All these well preserved sites have been incorporated in Natura 2000 European network as Sites of Community Importance (SCI) and/or Special Protection Areas (SPAs) (Buffa \& Lasen, 2010).

\section{Landscape classification}

\subsection{Background}

Modern ecology relies on the concept of ecosystem as a fundamental concept to consistent environmental policy making. As provided in Article 2 of the Convention on Biological Diversity (1992), ecosystem means a "dynamic complex of plant, animal and micro-organism communities and their non-living environment interacting as a functional unit".

From a nature conservation point of view, main concerns should be focused on spatial extension of ecosystems and their quality, as well as on their adaptability and recovery potential. As different ecosystems types are not equally valuable or equally susceptible to human-induced environmental change, to ensure ecologically sound management aimed at sustainability and preservation of biodiversity, ecosystems need to be described, characterised and spatially located (Blasi et al., 2000; Rowe, 1996; Sims et al. 1996).

The increasing attention to biodiversity conservation and natural resources management has reawakened the interest in ecosystem classification and mapping, mostly focusing on flexible and vertical, namely hierarchical, methods (Acosta et al., 2005; Klijn \& Udo de Haes 1994; Matson \& Power, 1996; Zonneveld, 1995), which can help dealing with the complex and dynamic nature of ecosystems providing instruments to refer to any functional unit at any scale depending on the problem being addressed. 
The basic idea is that different ecosystems are detectable as a function of their homogeneity, which depends on the scale of observation. The importance of scale is universally recognized as scale concerns all types of ecological data and it is a fundamental facet of ecological heterogeneity, whose interpretation depends on the level of observation established when studying an ecological system (Levin 1992; Rescia et al., 1997).

Hierarchical structuring of communities and ecosystems has been long recognized (Allen \& Starr, 1982; O'Neill et al., 1986) and it basically means that, at a given scale, any biological system is composed of lower-level interacting components and, at the same time, is itself an element of a greater system (O'Neill et al., 1989). The recognition of spatially defined landscape units can thus be useful for stratifying landscapes into ecologically homogeneous units, whose patterns and functions, at each level, depend on both the potentiality of lower levels and the restraints imposed by higher levels (O'Neill et al., 1989). Ecosystem classification set up on the hierarchical concept can thus provide interconnected spatial units with different potential purposes, depending on the scale of the problems under investigation and the requisite precision of the results (Carranza et al., 2008).

Blasi et al. (2000; 2005) have recently proposed a hierarchical framework designed for describing and mapping Italian landscapes at different levels. It is a deductive and spatial explicit method based on the homogeneity of the physical environment aiming at defining land units with different vegetation potential (Blasi \& Frondoni, 2011). According to the method, land attributes used for classifying landscapes are those widely recognized (Forman \& Godron 1986; Zonneveld 1995) as ecologically relevant: climate, lithology, geomorphology, human activities, soil and vegetation, ordered from the most stable factors controlling processes occurring at larger ecological scales to more dynamic ones working at local levels, so reflecting their hierarchy both in time and space.

All these landscape attributes are integrated with the concept of potential natural vegetation (PNV). This concept is one of the most important concepts developed within plant ecology since it allows the provisioning of predictive models of plant communities dynamics (Biondi, 2011). The concept was firstly formalized by Tüxen (1956) and it can be defined as the plant community that would develop in a given habitat if all human influences would stop (Westhoff \& van der Maarel, 1973); in other words, it delineates the spontaneous natural development of landscape within a homogeneous land unit. The concept of PNV correlates to that of vegetation series which is composed of dynamically linked plant communities developing into the same type of mature vegetation, i.e. the PNV (Biondi, 2011; Blasi et al., 2005).

The top-down, deductive approach supports the identification of homogeneous units which can be then classified according to the inner dynamic vegetation pattern.

From higher to lower level, Blasi's framework includes (Blasi et al., 2000; 2005):

- $\quad$ Land Regions (LR): represent the broadest level (scale $>250.000$ ); identified by means of macroclimatic features;

- $\quad$ Land Systems (LS): delimited according to significant lithological differences; 
- Land Facets (LF): delimited through lithomorphological features (altitude, slope and aspect) and local bioclimatic types (rainfall and temperature regimes);

- Land/Environmental Units (LU): defined at a smaller scale (1:10.000/1:50.000), they are determined by a major vegetation series that evolves in one consequent PNV type.

- $\quad$ Land Elements (LE): correspond to the different plant communities.

Although successfully applied to different ecosystems (Acosta et al., 2003a; 2005; Blasi et al., 2004; 2005; Stanisci et al., 2005), the method appears less workable in sandy coastal landscape, where the identification of single land elements is quite impossible at the scale proposed. For this reason, according to the proposal of Carranza et al. (2008), in this study LU have been described through coastal dune geosigmeta which can be defined as a mosaic of adjoining vegetation series within a geomorphologic, biogeographical and bioclimatic unit (Biondi 1994; Blasi et al., 2005).

\subsection{Application to N-Adriatic coastal dunes}

Land Regions, Systems, Facets and Environmental Units of N-Adriatic coastal dunes were obtained by overlaying physical information digitalized as GIS data vector layers in ArcGIS 9.3 (Environmental Systems Research Institute [ESRI], 2008). As the entire studied area is included in the same macroclimate zone, starting thematic maps were a geological map (Bondesan et al., 2008), a geomorphological map (Bondesan \& Meneghel, 2004) and a pedological map (Bini et al., 2002; Ragazzi et al., 2005; Ragazzi \& Zamarchi, 2008). Bioclimatic characterization was set up according to Rivas-Martinez (2008) using data (19922010) from seven weather stations located all along the Venetian coastline.

Information concerning land elements distribution (potential coastal vegetation-zonation) was obtained using the phytosociological approach (Braun-Blanquet, 1964). Both up-to-date original data (41 surveys) and data from previous phytosociological studies (204 surveys) were used (Gamper, 2002; Gamper et al., 2008; Géhu et al., 1984; Poldini et al., 1999; Sburlino et al., 2008). Vegetation surveys (phytosociological relevés) were combined in a single matrix and classified by cluster analyses to be assigned to syntaxonomic taxa according to their floristic, structural and coenological features (Westhoff \& van der Maarel, 1973).

\subsection{Results}

The entire study area belongs to the same Land Region and Land System (Table 2).

Rainfall and temperature regimes differentiated an upper Mesotemperate upper sub-humid climate northwards and a lower Supratemperate lower sub-humid climate, with a steppic variant, southwards allowing the identification of two different Land Facets (LF) which are separated by the Piave River that seems to act as a bioclimatic divide. Northern Land Facet (NLF) extends from the Tagliamento River to the Piave River; Southern Land Facet (SLF) from the Piave River to the Brenta-Adige-Po Rivers system in the south (see map in Figure 1).

Main land elements are summarized in Table 3 and grouped according to PNV classes. 


\begin{tabular}{|c|c|c|c|c|}
\hline LR & LS & LF & EU & LE \\
\hline \multirow{6}{*}{ 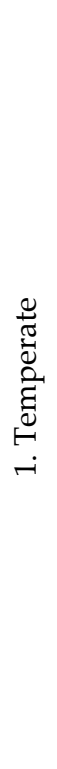 } & \multirow{6}{*}{ 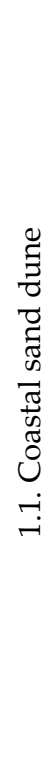 } & \multirow{3}{*}{$\begin{array}{l}\text { 1.1.1. recent coastal dunes } \\
\text { under upper Mesotemperate } \\
\text { upper sub-humid climate }\end{array}$} & \multirow{3}{*}{$\begin{array}{l}\text { 1.1.1.1. } \\
\text { Coastal dune } \\
\text { geosigmetum }\end{array}$} & $\begin{array}{l}\text { 1.1.1.1.1. Beach and } \\
\text { mobile dunes }\end{array}$ \\
\hline & & & & 1.1.1.1.2. Fixed dunes \\
\hline & & & & $\begin{array}{l}\text { 1.1.1.1.3. Dune slack } \\
\text { transition to alluvial } \\
\text { deposits }\end{array}$ \\
\hline & & \multirow{3}{*}{$\begin{array}{l}\text { 1.1.2. recent coastal dunes } \\
\text { under lower Supratemperate } \\
\text { lower sub-humid climate, } \\
\text { steppic variant }\end{array}$} & \multirow{3}{*}{$\begin{array}{l}\text { 1.1.1.2. } \\
\text { Coastal dune } \\
\text { geosigmetum }\end{array}$} & $\begin{array}{l}\text { 1.1.1.2.1. Beach and } \\
\text { mobile dunes }\end{array}$ \\
\hline & & & & 1.1.1.2.2. Fixed dunes \\
\hline & & & & $\begin{array}{l}\text { 1.1.1.2.3. Dune slack } \\
\text { transition to alluvial } \\
\text { deposits }\end{array}$ \\
\hline
\end{tabular}

Table 2. Land Region (LR), System (LS), Facets (LF), Environmental Units (EU) and Elements (LE) of the Venetian coastal dune systems.

Each Environmental Unit is set up by three systems in contact with each other (Figure 3). The variation of structural types (namely, different life forms that dominate and characterize different plant communities) along the zonation is that typically found in sandy coastal systems worldwide (Biondi, 1999; Carboni et al., 2009; Frederiksen et al., 2006; Sykes \& Wilson, 1991). The zonation develops moving inland from the sea edge along the steep environmental gradient, with the most pioneering annual communities on the beach and the woods in the inland sheltered zone.

Apart from the fixed zonation determined by their ecological requirements, N-Adriatic sandy coastal plant communities show a certain degree of uniqueness within the Mediterranean Basin (Pignatti, 1959; Géhu et al., 1984; Gamper et al., 2008; Sburlino et al., 2008), which is supported by various factors ranging from the present geographical and physical characteristics to the past climatic events that drove wide floristic migrations in Northern Italy. The synergy of all these features makes possible the presence of a wide range of species with different geographical distribution encompassing temperate, Mediterranean, western, eastern and mountain species (the latter mainly in the Northernmost part of the coast, carried downwards by torrential rivers like the Tagliamento and the Piave). This singular phytogeographic blend, also recognized for other north-eastern Italian ecosystems (Buffa \& Villani, 2012), greatly increases the floristic value of this area, contributing to define plant communities and systems not found elsewhere (Lorenzoni, 1983; Buffa et al., 2007). 


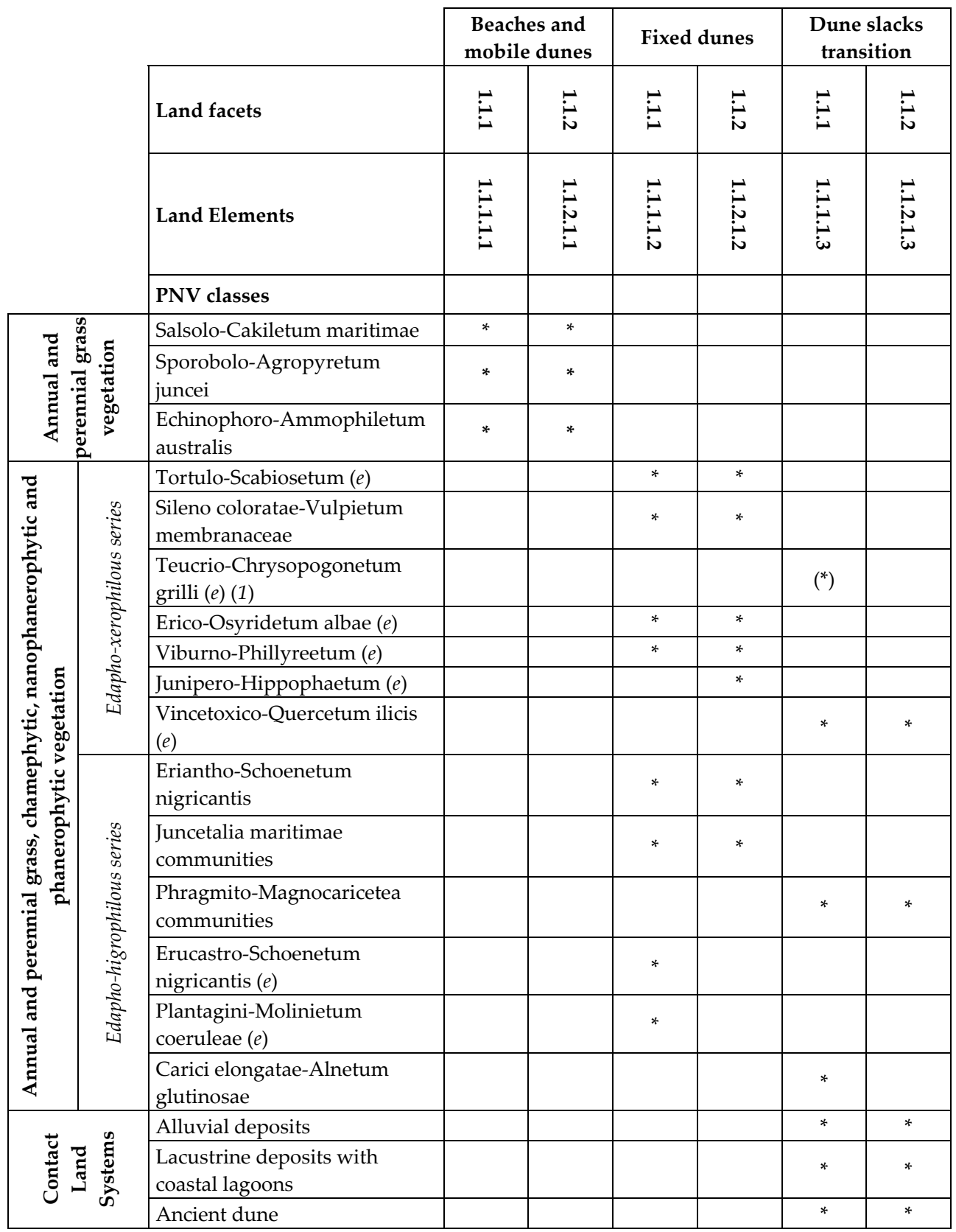

Table 3. Potential natural vegetation types that characterize coastal dune ecosystem zonation on the NAdriatic coast. Asterisks point to the presence of the different plant communities; $(e)$ indicates endemic plant communities; (1) Teucrio-Chrysopogonetum grilli dry grasslands are present only on ancient dunes located out of the surveyed area. 
B

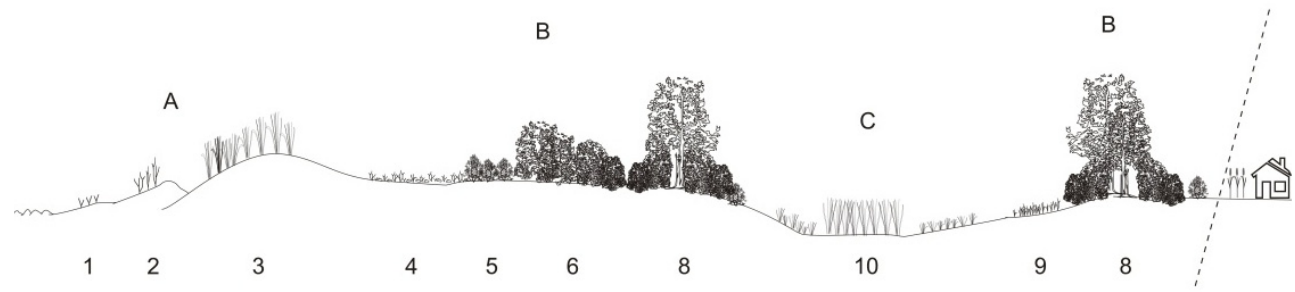

Southern Land Facet

B

B

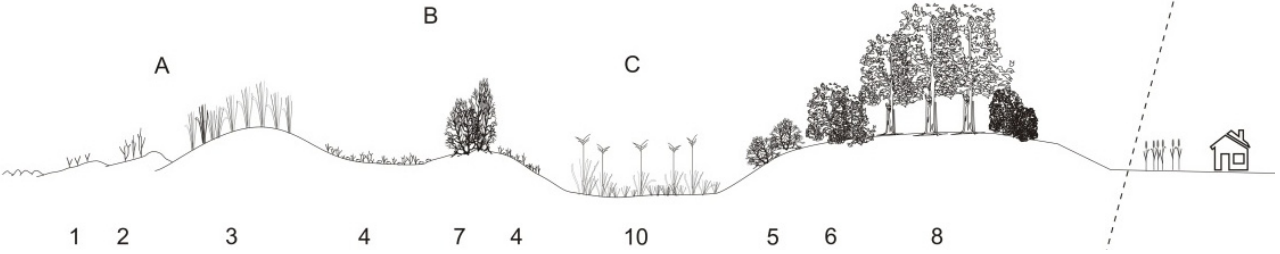

Figure 3. Simplified representation of the Potential Natural Vegetation (PNV) along the N-Adriatic coast. A=Beach and mobile dunes; $\mathrm{B}=$ Edapho-xerophilous series; $\mathrm{C}=$ Edapho-higrophilous series. 1=Salsolo-Cakiletum maritimae; 2=Sporobolo-Agropyretum juncei; 3=Echinophoro-Ammophiletum australis; 4=Tortulo-Scabiosetum; 5= Erico-Osyridetum albae; 6=Viburno-Phillyreetum angustifoliae; $7=$ Junipero-Hippophaetum fluviatilis; 8= Vincetoxico-Quercetum ilicis; 9=Teucrio-Chrysopogonetum grilli; 10=higrophilous mosaic.

The sandy coastal system begins with the pioneer, nitrophilous community dominated by annuals of the strandline zone (Salsolo kali-Cakiletum maritimae plant community); being exposed to wave inundation, salt spray and wind stress, the community is often patchy and fragmented. Beach land elements are species-poor communities, since few species can survive the stress and disturbance of sand mobility and salt spray (Nordstrom et al., 2009). Pioneer plants of Salsolo-Cakiletum are tolerant of salt spray and sand blasting and contribute to the formation of embryo dunes on the backshore while grasses form foredune ridges (Seabloom \& Wiedemann, 1994). The Cakile maritima plant community is then followed by that of embryo dunes dominated by dune-forming plants such as Elymus farctus (SporoboloAgropyretum juncei). On mobile dunes (white dunes) the Ammophila arenaria community (Echinophoro spinosae-Ammophiletum australis) establishes; Ammophila arenaria is the dominant species and is responsible for stabilizing and building up the foredune by capturing blown sand and binding it together with its tough, fibrous rhizome system (Chapman, 1976). Beaches and mobile dunes soils are shallow, sandy, calcareous, mesic Typic Xeropsamments or Typic Udipsamments (Bini et al., 2002), depending on local topographical conditions, and have very low organic carbon content and scarce horizons differentiation.

Landward of the foredune crest, increased protection from physical stresses allows the development of woody shrubs in the seaward slopes of the dune and trees and upland 
species in the landward portions. The inner, more stable dunes host more developed soils: they are thicker and have better horizons differentiation with blocky structure, higher organic carbon content and higher Available Water Capacity (AWC). Depending on the soil moisture regime, they can be classified as Typic Haploxerepts, Arenic or Typic Eutrudepts (Bini et al., 2002). Consequently, vegetation evolves towards more structured forms, such as medium and high shrubs and ends in the forest dominated by holm-oak. Then, moving inland, mobile dunes systems are spatially replaced by the edapho-xerophilous series of fixed dunes, entirely composed of N-Adriatic endemic communities (Gamper et al., 2008). The series begins with a perennial dry microprairie (Tortulo-Scabiosetum) dominated by dwarf shrubs, perennial herbaceous species, mosses and lichens, that covers fixed dunes (grey dunes). On inland ancient dunes, it is replaced by an endemic dry grassland (Teucrio capitati-Chrysopogonetum grylli), whose structure is mainly characterized by perennial herbaceous species and lower dwarf shrubs cover. The coastal zonation ends in the dune slack transition with Quercus ilex woods (Vincetoxico-Quercetum ilicis). This community is currently present although scattered and fragmented as a consequence of agricultural claim, but it shows a good recovery potential under the canopy of senescent pine forests.

Intermediate communities (Viburno-Phillyreetum angustifoliae and Erico-Osyridetum albae) and the pseudo-macchia (Junipero-Hippophaetum fluviatilis) of the seaward side of the semiconsolidated dunes and fixed dunes, exposed to wind action, complete the zonation. Woody communities contribute to outline the biocenotic uniqueness of $\mathrm{N}$-Adriatic coasts relative to Mediterranean coastal sand dune systems: particularly the widespread presence of Juniperus communis ssp. communis suggests links towards Atlantic coasts rather than Mediterranean ones (Gamper et al., 2008).

Interdunal depressions are colonized by wet grass communities (the edapho-hygrophilous series and the sub-halophilous mosaic of wet infradunal downs). The most interesting are the hygrophilous natural fens (Erucastro-Schoenetum nigricantis) and the semi-natural meadows (Plantagini altissimae-Molinietum caeruleae), both endemic, growing on neutral to subalkaline soils enriched in organic matter. Molinia caerulea grasslands are a very rare seminatural community, found where the water table is close to the surface, and its long term conservation needs constant agricultural management such as regular mowing. Managing slowdown determines littering, auto-manuring and development of common shrubs and woody vegetation. Soils of interdunal lowlands somehow resemble those of shallow dunes (coarse texture, subalkaline reaction, scarce horizons differentiation), but with an aquic soil moisture regime, reducing conditions and a slightly saline water-table, at least close to the coastline. Under these conditions, the Schoenus nigricans and Erianthus ravennae community (Eriantho-Schoenetum nigricantis) is the most widespread, although patchy and fragmented.

Inland wetland areas present counteracting aspects, since they are of interest both as regulators of hydrological conditions and for biodiversity conservation. They are characterized by soils with coarse-loamy texture, subalkaline reaction, organic matter accumulation, and a fresh water-table close to the surface (Bini et al., 2002). Plant communities change according to the water-table level and the nutrient content, from the hydro-hygrophilous cane brake (Phragmition communis communities) to fens and wet 
meadows (Caricion davallianae, Magnocaricion elatae and Molinietalia caeruleae). Further development would foresee the marshy willow shrub (Frangulo-Salicetum cinereae) and the black alder wood (Carici elongatae-Alnetum glutinosae), nevertheless still found only in a small patchy area southward.

Coastal dune vegetation has been often described as azonal (Acosta et al., 2003a; Buffa et al., 2007); this is mostly true for communities of beaches and mobile dunes which actually have been proved to have a wide geographical range (Biondi, 1999; Carranza et al., 2008). On the contrary, foredune systems, and particularly the edapho-xerophilous series, are delineated by floristic and coenological features which are more related to local conditions such as climate, morphology, lithology and history. In the study area, all these aspects give rise to an outstanding environment so explaining the high level of cenological endemism.

Compared to the xerophilous series, wetland systems are structurally simplified and host a lower number of plant species, usually with wide distributional range (Buffa et al., 2007), but their presence, though extremely patchy and scattered, contributes to increase the NAdriatic landscape richness and diversity.

Although the two Land Facets show the same systems sequence (beach and mobile dunesfixed dunes-dune slacks transition) they slightly differentiate in terms of number of land elements and landscape diversity. It is worth noting that the simplified landscape representation drawn in Figure 3 and the series described in Table 3 only represent the potential natural landscape of N-Adriatic sandy costal system but almost nowhere does it actually express from beach to dune slacks transition completely.

Particularly the most complex communities, i.e. woody communities, have almost disappeared and persist only scattered and patchy. The pseudo-macchia (JuniperoHippophaetum), which only 30 years ago was widespread (Géhu et al., 1984), currently exists just in one site (Porto Caleri), thanks to the establishment of a protected area in 1991.

Despite anthropogenic pressure and changes in the coastal dune environment of the NAdriatic coastline, 20 EU habitats of interest (EU 43/92) have been surveyed. Therefore, regardless of human pressures, the Venetian coastal ecosystem could be regarded as a biodiversity hotspot within the Mediterranean Basin and still conserves many valuable elements to be maintained and emphasized (Buffa \& Lasen, 2010).

\section{Assessing conservation status}

\subsection{Background}

The increased rate of habitat change and natural resource utilization since the 1950s, and the consequent threats to biodiversity have led to increased concern for monitoring and protecting remaining natural areas.

$\mathrm{N}$-Adriatic coastal dune system suffers from a severe and complex human utilization; meanwhile it holds high landscape, faunal and floral values. These characteristics make it an ideal site to test an analytical approach to conservation status assessment to provide 
management policy which takes into account ecological values, landscape complexity and driving processes.

In the late 1980', Franklin et al. (1981) recognized three primary attributes of ecosystems: composition, structure, and function, which frame and make up the biodiversity of an area. Composition concerns the identity and variety of elements and includes measures of species diversity; structure represents the physical pattern of a system, from habitat complexity to the landscape level; finally, function relates to ecological and evolutionary processes, such as gene flow, disturbances and nutrient cycling (Noss, 1990).

Recently, progress has been made in developing methods for monitoring compositional diversity and for assessing threats of individual species, mostly in support of the IUCN Red List (Akcakaya et al., 2000; IUCN, 2006). This approach has become so overriding, that ecosystems evaluation is commonly based on the proportion of the threatened or endemic species pool that they encompass (Bonn \& Gaston, 2005). Much less advancement has been made in building up an adequate insight into structural and functional diversity and in developing sound methods for assessing threats to habitats and ecosystems. Consequently, structural simplification of ecosystems which leads to the disruption of fundamental ecological processes can remain unappreciated.

The well known complexity of biodiversity and its hierarchical organization make clear that composition, structure and function of ecosystems are interdependent, nested and bounded (Noss, 1990; Margules \& Pressey, 2000). These two concepts lead to two main consequences: first, because of the complexity of biodiversity, conservation status assessment can be defined using surrogates or partial measures such as sub-sets of species, species assemblages and habitat types (Hermy \& Cornelis, 2000; Margules \& Pressey, 2000). In particular, plant communities and vegetation, owing to their specific nature, can be regarded as good indicators of overall biodiversity and specifically of ecosystem integrity of coastal dune ecosystems (Araújo et al., 2002; Carboni et al., 2009; Géhu \& Biondi, 1994; Géhu \& Géhu, 1980; Lopez \& Fennessy, 2002). Second, hierarchy theory suggests that monitoring and assessment can not be limited to one single level of organization and that different levels of resolution are proper for different questions (Noss, 1990; Bonn \& Gaston, 2005). Hence, a thorough analysis of the conservation status of landscapes should take into account multiple levels of biodiversity, from community level to the entire landscape, considering compositional and structural features as well. This can be performed choosing a consistent and multiscale set of key indicators, based on field data, embodying the entire complexity of the vegetation system (Carboni et al., 2009; Cingolani et al., 2010; Hermy \& Cornelis, 2000).

\subsection{Methods}

According to a previous research (Buffa et al., 2005) bound to a small coastal area, the conservation status of N-Adriatic coastal landscape has been estimated at two different interconnected scales: at landscape and plant community level. The method has been slightly redefined following the recent proposal by Carboni et al. (2009) and Grunewald \& Schubert (2007). 
Assessment method grounds on the basic idea that the severe and stressing dunal environment is the dominant factor leading not only to the presence of highly adapted and specialized species and communities (which refers to the identity and variety of elements) but also to a typical and worldwide sea-inland spatial zonation of plant communities (i.e., the physical pattern of the system), which in absence of disturbance events tends to be fixed.

We limited our evaluation only to those PNV with a xeric soil moisture regime, namely "beaches and mobile dunes" and the edapho-xerophilous series of fixed dunes and dune slack transition (see Table 3); as for the edapho-higrophilous series, it was included in "natural surface" category.

\subsubsection{Landscape level}

Analysis were carried out on the basis of a digital map of the area $(1: 10.000)$ encompassing the major natural land cover types as well as artificial surfaces. Natural land elements belonging to coastal zonation were expressed in terms of EU habitats (following EU Habitat Directive).

The map was derived from panchromatic digital aerial ortho-photographs (dated 2010) with a resolution of $6000 \times 5600$ pixels, covering $1500 \mathrm{~m}$ wide stretch from the coastline inward. Land cover was manually interpreted on video, by means of a Geographic Information System (ArcGIS software 9.3), and field survey. The legend follows CORINE land cover expanded, where possible, to a fourth level of detail. If a CORINE land cover category embodied more than one EU habitat (i.e., 3.2.2.2 Termophilous shrubs), it has been accordingly split up.

GIS analysis tools were used to calculate some common landscape metrics (Table 4) regarding both composition and structure. Landscape metrics were figured out for the entire studied coastal stretch to define an overall conservation status; at the same time they allowed a comparative evaluation of the status of PNV land elements and landscape inside the two Land Facets recognized in the area.

\begin{tabular}{ll}
\hline Composition & Structure \\
\hline Total LC type richness & Total number of patches \\
Natural LC type richness & Number of natural patches \\
Natural coastal LC type richness & Number of natural coastal patches \\
Total surface (ha) & Average natural patch size (ha) \\
Percent natural surface & Mean shape index for natural patches (MSI) \\
Percent natural coastal vegetation & \\
Percent urban surface & \\
Percent agricultural surface & \\
Shannon Diversity Index $(\mathrm{H})$ & \\
Eveness $(\mathrm{J})$ & \\
\hline
\end{tabular}

Table 4. Indices of landscape composition and structure used for assessment. 
Landscape composition was evaluated in terms of richness and abundance of the main land cover categories. Particularly urban surface abundance, which causing physical changes strongly influence natural habitat, has been deepened as an indicator of human pressure to natural landscape (Margules \& Pressey, 2000; McKinney, 2002). Finally, richness and abundance parameters of each single category have been utilized to compare Shannon diversity index $(\mathrm{H})$ and evenness $(\mathrm{J})$ of the two Land Facets.

Landscape structure was analyzed by means of statistics such as number of patches of each land cover category, mean patch size and their mean shape index. Patch shape and size are important structural features of the landscape mainly related to the concept of "edges", which have been recognized as functional components of the landscape (Cadenasso \& Pickett, 2001; Forman, 1995), influencing fluxes of organisms, material, and energy between two adjacent habitats.

Patches spatial arrangement allow the quantitative measurement of heterogeneity of a landscape and the comparison of landscapes, while shape index evaluates landscape configuration in terms of the complexity of patch shape (McGarigal \& Marks, 1995). Patton's shape index (Patton 1975) was chosen, among others, because it measures the complexity of patch shape compared to a standard shape (a circular standard) the same size, thus alleviating the size dependency problem. As natural communities of coastal ecosystems usually run stretched out parallel to the coastline, then high MSI values will testify for natural patterns, while less natural typologies or fragmented patches, with more isodiametric or round forms, will show lower MSI values (Carboni et al., 2009).

\subsubsection{Community level}

Number of categories, their proportions and diversity represent non-spatial system properties (Gustafson, 1998) mostly linked to compositional features, but composition being equal a landscape may exhibit many different patch arrangement, that is many different spatial configuration. When undisturbed, plant communities of sandy coastal ecosystems show a typical distribution pattern along the sea-inland gradient which can thus represent a reference model for evaluating actual spatial configurations.

Spatial configuration integrity was measured by means of richness of boundaries, $n$ (Rescia et al., 1997) and the gamma connectivity, y (Acosta et al., 2000; 2003b; Forman \& Godron, 1986). According to Acosta et al. (2003b), the two indices were calculated through a one-dimensional approach which involves the projection of the plant communities found along sea-inland transects perpendicular to the coastline. Therefore, each transect presents a specific spatial sequence of plant community patches, which can be compared with the reference model.

The number of different types of boundaries (i.e. contacts between plant community types) along each transect represents $n$, the richness of boundaries, while gamma connectivity index refers to the position of a patch type in relation to other patch types and determines the boundary between patches and the links among them. Gamma connectivity index ranges from 0 (no links among patches) to 1 (every patch is linked to every possible patch), and higher values are normally considered an index of better environmental quality 
(Forman, 1996). On the contrary, in coastal dune systems, where plant communities tend to have a strong linear distribution, the best structural quality reflects the natural and undisturbed sequence which has a low number of fixed links. Therefore, higher connectivity values are usually associated to disturbance events which destroy or modify the natural sequence. The two indices have been calculated along 30 transects arranged along the coastline at $3500 \mathrm{~m}$ interval, 10 in NLF and 20 in SLF.

Besides, for each plant communities we computed some indicators of species diversity and vegetation quality. We estimated the diversity of plant communities by calculating the diversity index and evenness, following the proposal by Grunewald \& Schubert (2007) who adapted Shannon diversity and evenness index specifically for coastal dunes, Hdune and Edune, incorporating the parameter "species density" (plant cover relative to the plot-size).

As aliens and ruderal species are predicted to increase as a result of increasing human disturbance (Richardson et al., 2000; Sax \& Gaines, 2003), an effect in overall diversity may be expected. Recently, Carboni et al. (2009) proposed relating the number of species of a broad distribution type or of exotic origin, which are generally introduced and/or favoured by human disturbance, to the number of species of a chorological type characteristic for the examined area and strictly dependent on the studied region. As one of the main characteristics of N-Adriatic region is just the co-occurrence of many different chorological types, choosing the most typical was not possible. Therefore, to provide information about quality, or inversely, about the level of "anthropogenization" we calculated a natural diversity index (N) (Grunewald \& Schubert, 2007). According to a common procedure in ecological and conservational studies (e.g., Grime, 2002; Martinez et al., 2004; Rodgers, 2002; Rodgers \& Parker, 2003), the degree of natural diversity $(\mathrm{N})$ was calculated by classifying species into typical native dune species and untypical dune species often associated with non-dune habitats and disturbed, nutrient-rich sites, including truly alien species as well. Being the ratio between diversity index Hdune computed with all species and that without "alien" species, the index $\mathrm{N}$ can be read as a sound evaluation of natural diversity; only a maximum value of one can be reached (if no species are excluded $=$ complete natural diversity) (Grunewald \& Schubert, 2007).

The significance of overall difference among communities in terms of diversity index, evenness and index $\mathrm{N}$ was assessed by one-way ANOVA on transformed data, in order to determine differences at the critical significance level $\mathrm{p}<0.01$. One-way ANOVA on transformed data was also used to check differences in quality (Hdune, Edune, $\mathrm{N}_{\text {dune }}$ ) between the two coastal LF at the critical significance level $p=0.05$. Finally, we tested differences in the spatial patterns (connectivity and richness of boundaries) and quality (Hdune, Edune, $\mathrm{N}_{\text {dune }}$ ) of the two Land Facets comparing values through independent groups $t$-tests (Sokal \& Rohlf, 1995).

\subsection{Results}

\subsubsection{Landscape level}

Land cover classification allowed the identification of 30 different CORINE Land Cover Types (Table 5), but as they could embody more than one habitats, total number of land categories summed up to 40 . 


\begin{tabular}{|c|c|c|c|}
\hline Level 1 & Level 2 & Level 3 & Level 4 \\
\hline \multirow{10}{*}{ 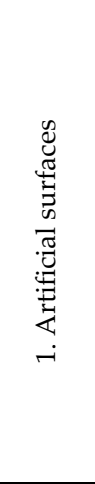 } & \multirow{2}{*}{ 1.1. Urban fabric } & 1.1.1. Continuous urban fabric & \\
\hline & & 1.1.2. Discontinuous urban fabric & \\
\hline & \multirow{4}{*}{$\begin{array}{l}\text { 1.2. Industrial } \\
\text { commercial and } \\
\text { transport units }\end{array}$} & 1.2.1 Industrial or commercial units & \\
\hline & & $\begin{array}{l}\text { 1.2.2. Road and rail networks and } \\
\text { associated lands }\end{array}$ & \\
\hline & & 1.2.3. Port areas & \\
\hline & & 1.2.4 Airports & \\
\hline & \multirow{2}{*}{$\begin{array}{l}\text { 1.3. Mine, dump and } \\
\text { construction sites }\end{array}$} & 1.3.2 Dump sites & \\
\hline & & 1.3.3. Construction sites & \\
\hline & \multirow{2}{*}{$\begin{array}{l}1.4 . \text { Artificial non- } \\
\text { agricultural vegetated } \\
\text { areas }\end{array}$} & 1.4.1 Green urban areas & \\
\hline & & 1.4.2. Sport and leisure facilities & \\
\hline \multirow{3}{*}{ 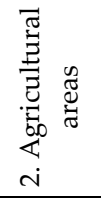 } & 2.1. Arable land & 2.1.1. Non-irrigated arable land & \\
\hline & 2.2. Permanent crops & 2.2.4 Other permanent crops & \\
\hline & $\begin{array}{l}\text { 2.4. Heterogeneous } \\
\text { agricultural areas }\end{array}$ & $\begin{array}{l}\text { 2.4.3. Land principally occupied by } \\
\text { agriculture, with significant areas of } \\
\text { natural vegetation }\end{array}$ & \\
\hline \multirow{10}{*}{ 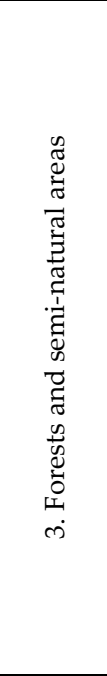 } & \multirow{3}{*}{ 3.1. Forests } & \multirow[t]{2}{*}{ 3.1.1 Broad-leaved forests } & \begin{tabular}{|l|}
$\begin{array}{l}\text { 3.1.1.1 Quercus ilex woods } \\
(9340)\end{array}$ \\
\end{tabular} \\
\hline & & & 3.1.1.6 Higrophilous woods \\
\hline & & 3.1.2. Coniferous forests & 3.1.2.1. Pine woods (2270) \\
\hline & \multirow[t]{2}{*}{$\begin{array}{l}\text { 3.2. Shrub and/or } \\
\text { herbaceous vegetation } \\
\text { association }\end{array}$} & 3.2.2. Moors and heathland & $\begin{array}{l}\text { 3.2.2.2 Termophilous shrubs } \\
\text { (2250/2160) (three different } \\
\text { plant communities) }\end{array}$ \\
\hline & & 3.2.4. Transitional woodland/shrub & \\
\hline & \multirow{5}{*}{$\begin{array}{l}\text { 3.3. Open spaces with } \\
\text { little or no vegetation }\end{array}$} & \multirow{5}{*}{$\begin{array}{l}\text { 3.3.1. Beaches, dunes, and sand } \\
\text { plains }\end{array}$} & 3.3.1.1. Open sand (1210) \\
\hline & & & $\begin{array}{l}\text { 3.3.1.2. Partially vegetated } \\
\text { dunes (2110) }\end{array}$ \\
\hline & & & $\begin{array}{l}\text { 3.3.1.3. Densely vegetated } \\
\text { dunes (2120) }\end{array}$ \\
\hline & & & $\begin{array}{l}\text { 3.3.1.4. Moderately } \\
\text { vegetated slacks (2130) }\end{array}$ \\
\hline & & & $\begin{array}{l}\text { 3.3.1.5 Interdune annual } \\
\text { grasslands (2230) }\end{array}$ \\
\hline \multirow{4}{*}{ 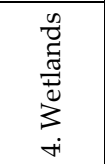 } & \multirow{2}{*}{ 4.1. Inland wetlands } & 4.1.1. Inland marshes & \\
\hline & & 4.1.2. Peatbogs & \\
\hline & \multirow{2}{*}{ 4.2 Coastal wetlands } & 4.2.1. Salt marshes & \\
\hline & & 4.2.3. Intertidal flats & \\
\hline \multirow{3}{*}{ 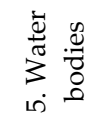 } & \multirow{2}{*}{ 5.1. Inland waters } & 5.1.1. Water courses & \\
\hline & & 5.1.2. Water bodies & \\
\hline & 5.2. Marine waters & 5.2.1 Coastal lagoons & \\
\hline
\end{tabular}

Table 5. CORINE land cover categories surveyed in the study area. For Level 4 correspondence with sandy coastal EU habitats is reported; numbers in brackets correspond to Natura 2000 codes. Note that some Natura 2000 habitats can be represented by more than one plant communities. 
Total surveyed area resulted in about 15.800 ha; $30.3 \%$ is covered by urbanized surface (mainly represented by towns and villages, roads and tourist facilities) and $22.2 \%$ by agricultural areas (mostly arable lands); only $47.5 \%$ is included in natural or semi-natural categories, of which only $4.5 \%$ represented by dune systems (Figure 4 and Table 6 ).
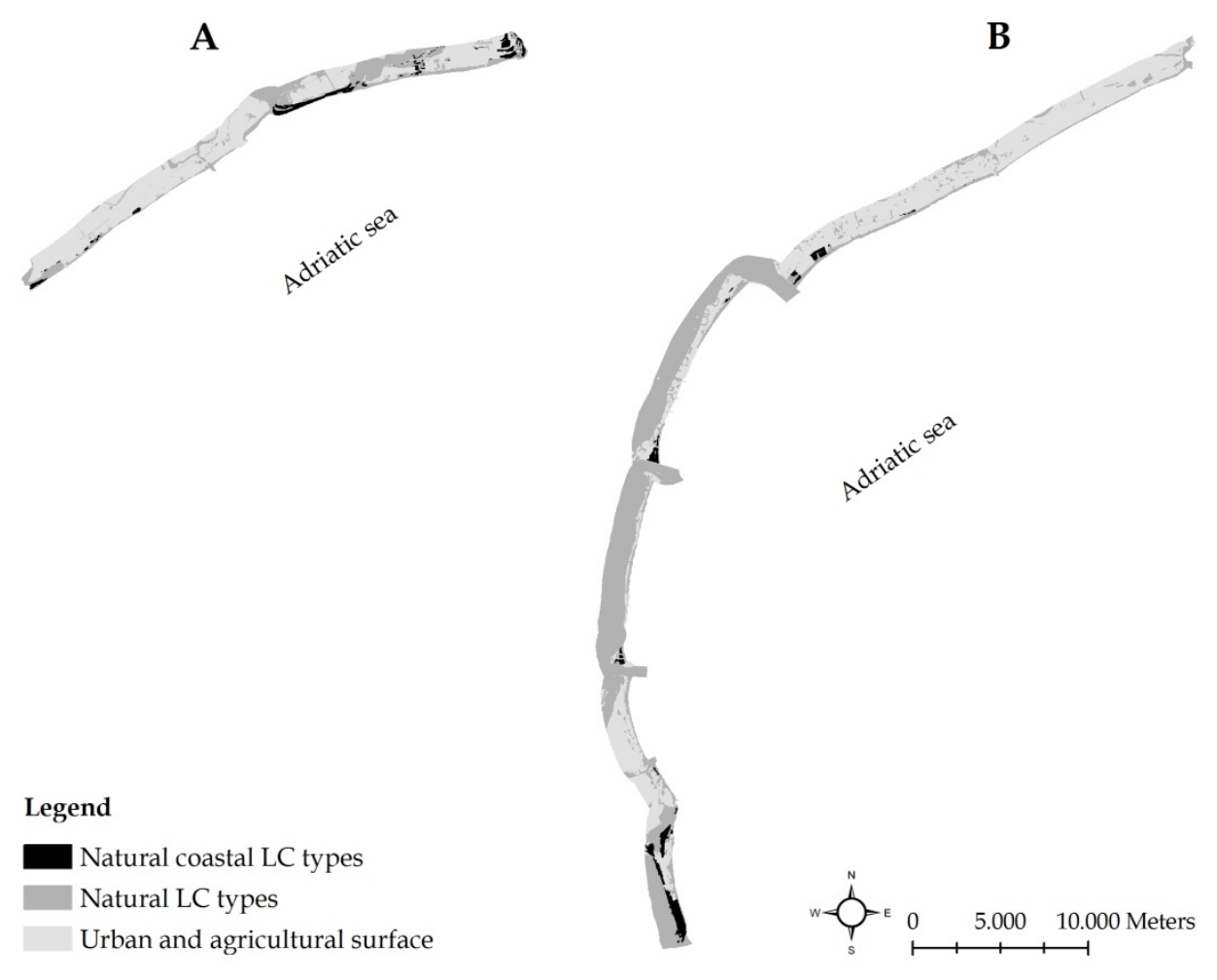

Figure 4. Land cover maps of the two Land Facets showing the main three categories as derived from the CORINE land cover map. A: Northern Land Facet, from Tagliamento River to Piave River; B: Southern Land Facet, from Piave River southwards to Brenta River.

Northern Land Facet (NLF) covers a surface of 4848 ha and extends from the Tagliamento River, in the north, to the Piave River; Southern Land Facet (SLF) covers a larger surface of 10942 ha, from the Piave River to the Brenta-Adige-Po Rivers system in the south.

As for composition, the two Land Facets resulted very similar. In NLF, the natural typologies were 25,8 of which were coastal ones; the SLF showed 25 natural typologies as well, 9 of which of natural coastal LC types. Abundance of natural LC types discriminated between the two Land Facets: of the total surface surveyed, only $36 \%$ was included in natural or semi-natural categories in the Northern part, while in the Southern more than $50 \%$ of the total surface fell in this category. Interestingly enough, while urban surface is quite similar (32\% in the north, $29 \%$ in the south), urbanization pattern differentiates; large and compact 
cities (such as Bibione, Caorle and Eraclea) predominate in the NLF, while in the SLF urban settlements permeate the landscape with some larger cities (like Jesolo) along with a continuous presence of houses, little villages and tourist facilities, whose spread is favoured by a more developed roads network. The situation is much impressive in the central part of SLF, corresponding to Venice barriers, where urbanization and widespread leisure facilities join a limited barriers width, leaving few sites for undisturbed natural vegetation. Therefore, although percentage of natural surfaces is lower in the Northern LF, they suffer from lower human pressure. Moreover, it is worth noting that the higher average size of natural patches in the SLF (Table 6) is mostly due to the presence of some categories such as coastal lagoons (i.e., particularly the Venice lagoon, in the central part) and salt marshes which usually cover broad areas.

\begin{tabular}{llll}
\hline variable & total & NLF & SLF \\
\hline Composition & & & \\
Total LC type richness & 40 & 36 & 37 \\
Natural LC type richness & 27 & 25 & 25 \\
Natural coastal LC type richness & 9 & 8 & 9 \\
Total surface (ha) & 15790.96 & 4848.79 & 10942.17 \\
Percent natural surface & 47.5 & 35.7 & 52.7 \\
Percent natural coastal vegetation & 4.5 & 5.8 & 3.9 \\
Percent on natural surface & & 16.1 & 7.4 \\
Percent urban surface & 30.3 & 31.8 & 29.6 \\
Percent agricultural surface & 22.2 & 32.5 & 17.6 \\
Shannon Diversity Index (H) (total surface) & & 2.52 & 2.34 \\
Eveness (J) (total surface) & & 0.70 & 0.65 \\
Shannon Diversity Index (H) (natural surface) & & 2.56 & 1.17 \\
Eveness (J) (natural surface) & & 0.80 & 0.36 \\
& & & \\
Structure & & & \\
Total number of patches & & 2790 & 5310 \\
Number of urban patches & 2.32 & 2.82 & 2.08 \\
Number of agricultural patches & 4397 & 1652 & 2745 \\
Number of natural patches & 507 & 119 & 388 \\
Number of natural coastal patches & 3196 & 1019 & 2177 \\
Average natural patch size (ha) & 458 & 214 & 244 \\
Average natural coastal patch size & 2.35 & 1.697 & 2.651 \\
Mean shape index for natural patches (MSI) & 1.54 & 1.303 & 1.743 \\
Mean shape index for natural coastal patches (MSI) & 2.11 & 2.05 \\
\hline
\end{tabular}

Table 6. Landscape composition and structure indices for total area and for each Land Facet examined (NLF=Northern Land Facet; SLF=Southern Land Facet). 
Total Shannon diversity index, calculated taking into account the proportions of each land cover category, reflects the situation, with a slightly higher diversity northwards. The dominance of coastal lagoons and correlated salt marshes also affects evenness, which is slightly lower for the SLF than for the NLF. Shannon diversity index and evenness, calculated taking into account only the proportions of natural land cover category, still strengthen differences (Table 6) between the LF.

The analysis of the entire area resulted in the identification of a total of 8100 patches, 3654 of which were natural ones, 458 of which represented by coastal vegetation patches (Table 6). The NLF coastal landscape was much more structured and heterogeneous, especially considering the natural coastal patches. In this area number of patches is lower, but they sum to $16 \%$ of the total natural patches cover against only $7 \%$ of natural coastal patches in the SLF.

The higher heterogeneity reflects on the average size of natural coastal patches, which is little more than a hectare for the former and nearly two for the latter $(t$-test, $\mathrm{p}<0.05)$. Mean shape index does highlight significant differences in the shape of the natural coastal patches of the two areas ( $t$-test, $\mathrm{p}<0.01)$, giving evidences, in the north, of a more natural landscape, where heterogeneity depicts typical features of coastal environments rather than a fragmented landscape, fruit of human disturbance.

Zooming inside the two land elements (beaches and mobile dunes and the edaphoxerophilous series of fixed dunes) helps to further clarify differences between Land Facets. Beaches and mobile dunes are much more abundant in the SLF, both in number of patches (123 against 35 ) and cover (25\% against 15\%), with a remarkable $10 \%$ covered by Ammophila arenaria community, which in NLF is almost replaced by an annual, nitrophilous community (Sileno-Vulpietum). Conversely, edapho-xerophilous series is much more widespread in the northern part and its importance is further underlined by the percentage cover of TortuloScabiosetum community, one of the rarest and most vulnerable coastal plant association of the Veneto Region, whose abundance is nearly three time than in the south.

\subsubsection{Community level}

The coastal zonation comprises ten plant communities grouped in nine different EU habitats, as code 2250 embodies both Erico-Osyridetum and Viburno-Phyllireetum communities. They range from the pioneer beach communities to the holm-oak wood in the inland part.

Plant species richness typically increased following the sea-inland gradient and ranged between 19 species in 29 samples from the upper beach (the Cakile maritima community) to 84 species in 38 samples from the transition dune vegetation (Tortulo-Scabiosetum community), with a slight decrease in the stabilized dunes (in particular Quercus ilex wood).

As expected, Hdune index followed the same trend (Table 7), evidencing highly significant differences between communities of beaches and mobile dunes and those of the edaphoxerophilous series, with higher values that concentrated in the intermediate communities of the latter (ANOVA, $\mathrm{p}<0.0001$, d.f. 195, $\mathrm{F}=27.09$ ). On fixed dunes, plant succession leads to 
more mature and complex plant communities than on mobile dunes, and more species are characteristically present. Evenness also changed from young successional stages to more mature stages. In the species poor communities of mobile dunes, dominance by one or two species is usually high. Once plant succession has led to more complex plant communities with higher mean coverage, interspecific competition for limited resources becomes the dominant factor limiting dominance and favouring equidistribution of species. Index of natural diversity $(\mathrm{N})$ showed an inverse trend and beaches and mobile dunes land elements were much more subject to invasion by human-favored ruderal or alien species. On the contrary, apart from Tortulo-Scabiosetum, intermediate and mature communities of the edapho-xerophilous series highlighted a very low degree of anthropogenization.

\begin{tabular}{llll}
\hline Quality of the vegetation & \multicolumn{1}{c}{$\mathrm{H}$ dune } & \multicolumn{1}{c}{$\mathrm{E}$ dune } & \multicolumn{1}{c}{$\mathrm{N}$ dune } \\
\hline Salsolo-Cakiletum & $0.583 \mathrm{a}$ & $0.743 \mathrm{a}$ & $0.702 \mathrm{a}$ \\
Sporobolo-Agropyretum & $0.906 \mathrm{~b}$ & $0.779 \mathrm{ab}$ & $0.673 \mathrm{ab}$ \\
Echinophoro-Ammophiletum & $0.804 \mathrm{abc}$ & $0.459 \mathrm{c}$ & $0.619 \mathrm{abc}$ \\
Sileno-Vulpietum & $0.91 \mathrm{bcf}$ & $0.79 \mathrm{ab}$ & $0.373 \mathrm{~g}$ \\
Tortulo-Scabiosetum & $1.540 \mathrm{~d}$ & $0.516 \mathrm{~cd}$ & $0.621 \mathrm{abc}$ \\
Erico-Osyridetum & $1.252 \mathrm{efg}$ & $0.575 \mathrm{cdef}$ & $0.984 \mathrm{de}$ \\
Viburno-Phyllireetum & $1.806 \mathrm{deh}$ & $0.627 \mathrm{ef}$ & $0.986 \mathrm{def}$ \\
Juniperum-Hippophaetum & $1.519 \mathrm{de}$ & $0.527 \mathrm{cde}$ & $0.964 \mathrm{~d}$ \\
Vincetoxico-Quercetum & $1.426 \mathrm{degh}$ & $0.402 \mathrm{ce}$ & $0.931 \mathrm{def}$ \\
\hline
\end{tabular}

Table 7. Indices of overall quality of plant communities of coastal zonation (paired $t$-tests; where letters differ, values are significantly different at $\mathrm{p}<0.01$ ).

As for the analysis of the spatial arrangement of communities along the zonation no significant differences emerged between the two Land Facets neither in the spatial connectivity index, nor in richness of boundaries (Table 8).

\begin{tabular}{lccc}
\hline variable & NLF & SLF & sig. \\
\hline Spatial structure & & & \\
Richness of boundaries (n) & 5.429 & 4.455 & 0.030 \\
$\gamma$ sea-inland & 0.537 & 0.603 & 0.325 \\
\hline
\end{tabular}

Table 8. Indices of spatial structure of the vegetation of the two Land Facets analysed (significance values refer to $t$-tests for independent groups; $\mathrm{df}=28$ ).

Richness of boundaries was hardly higher for the NLF as a consequence of the higher heterogeneity of this area, but the difference is only slightly significant. Moreover, the relatively high connectivity average values gave evidence for disturbance for both Land Facets, causing fragmentation of the communities and their repeated presence along the transects.

In Figure 5, some explanatory transects have been reported as examples. The comparison to reference model depicted in Figure 3 described two different disturbance patterns which confirmed the spatial and structural analysis. Transects of NLF mostly lacked first terms of 
zonation and the sequence started with open sand immediately followed by the edaphoxerophilous series and the edapho-higrophilous mosaic (both fresh and sub-halophilous communities where water-table was slightly saline). Conversely, in SLF edaphoxerophilous series is well conserved only in a few sites (see transect G); first terms of the sequence are much more widespread and sometimes well developed (see transect F), but in general their width is compressed by impending human settlements (see transect E).

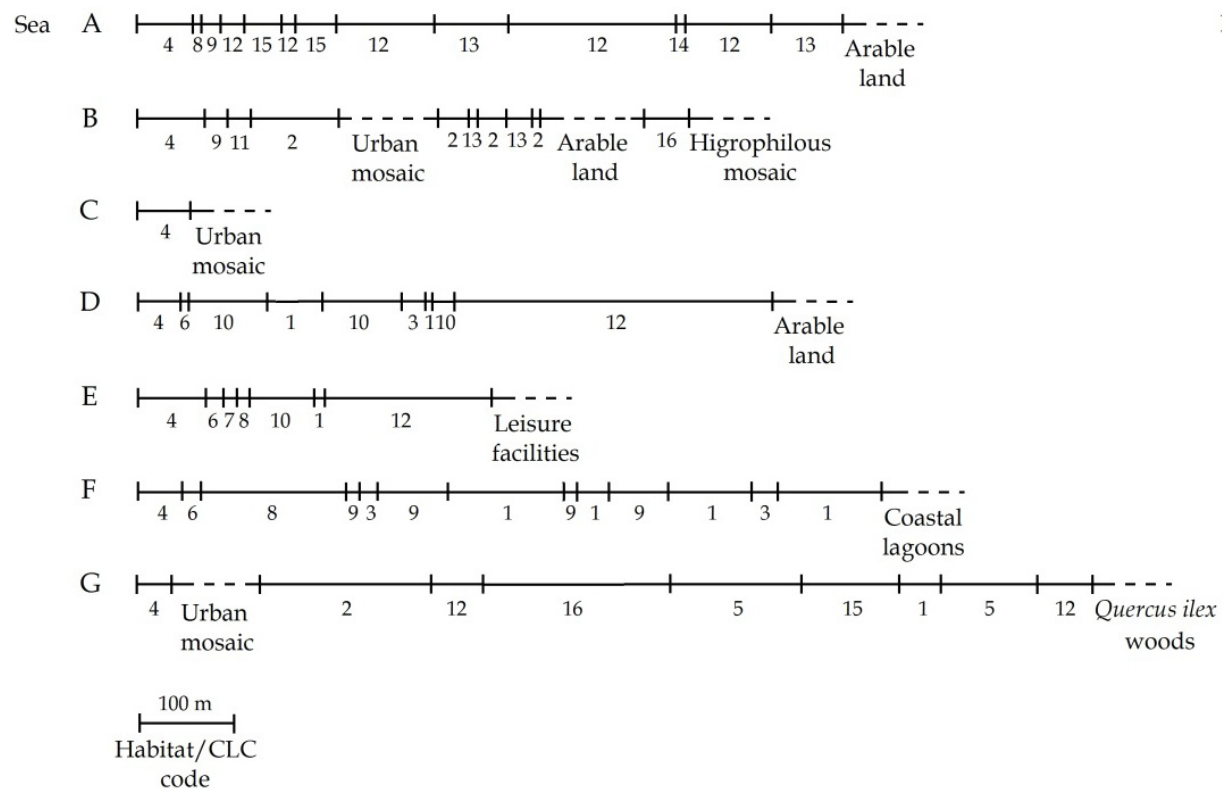

Figure 5. Schematic transects reporting sequence of natural and artificial land cover categories. Transects A and B are representative of NLF; in particular, transect A comes from the northernmost part corresponding to the Tagliamento mouth. Transects C-G come from SLF; F and G represent the sequence in Porto Caleri, at the southern boundary. $1=3.1 .1$. Broad-leaved forests; $2=3.1$.2. Coniferous forests; $3=3.2 .4$. Transitional woodland/shrub; $4=3.3 .1$. Beaches, dunes, and sand plains; $5=4.2 .1$. Salt marshes; 6=3.3.1.1. Open sand (1210); $7=3.3 .1 .2$. Partially vegetated dunes (2110); 8=3.3.1.3. Densely vegetated dunes (2120); 9=3.3.1.4. Moderately vegetated slacks (2130); $10=3.3 .1 .5$. Interdune annual grasslands (2230); 11=3.2.2.2. Termophilous shrubs (2250/2160) (three different plant communities); 12=3.1.2.1. Pine woods (2270); 13=4.1.1. Inland marshes; $14=4.1 .2$. Peatbogs; $15=3.1 .1 .6$. Higrophilous woods; 16=3.1.1.1. Quercus ilex woods (9340).

Diversity and evenness indices, calculated taking into account only the proportions of coastal communities found in the two Land Facets, and particularly $\mathrm{N}_{\text {dune, the }}$ index of natural diversity, confirmed differences (Table 9). Apart from evenness, which never differentiated ( $E$ and Edune), other indices were significantly higher for the dune system of NLF than for that of SLF indicating a richer and more diverse vegetation for the former. The better conservation status of the edapho-xerophilous series, which have been mostly eliminated in the southern area as a consequence of agricultural activities and leisure facilities development, is probably responsible for such higher diversity values. 
The better conservation status in NLF has been also reinforced by the significant difference emerged for the $\mathrm{N}$ index. In this case, $\mathrm{N}$ represented the ratio between $\mathrm{H}$ calculated taking into account the cover of all communities and that without cover of "alien" communities. Values were significantly different and in the NLF, N index was nearly 1 (that is, almost no communities have been excluded), clearly highlighting how human pressures facilitate natural communities replacement by ruderal, not typical communities such as SilenoVulpietum, in the seaward slopes of the dunes, or by dynamic stages characterized by transitional woods and shrub communities, landwards.

\begin{tabular}{lrrll}
\hline variable & NLF & SLF & \multicolumn{1}{c}{ F } & \multicolumn{1}{c}{$\mathrm{p}$} \\
\hline Shannon Diversity Index $(\mathrm{H})$ & 1.540 & 1.137 & 18.13 & $\mathrm{p}<0,0001$ \\
Eveness $(\mathrm{J})$ & 0.582 & 0.550 & n.s. & n.s. \\
Hdune & 1.521 & 1.041 & 24.24 & $\mathrm{p}<0,0001$ \\
Edune & 0.553 & 0.604 & n.s. & n.s. \\
$\mathrm{N}$ & 0.927 & 0.677 & 34.14 & $\mathrm{p}<0,0001$ \\
\hline
\end{tabular}

Table 9. Differences in quality between NLF and SLF (one-way ANOVA; $\mathrm{df}=195$ ).

\section{Discussion and conclusion}

Coastal areas are responsive systems affected by natural as well as anthropogenic pressures. Specifically, coastal sand dune dynamics, not only that linked to human disturbance, but even the natural cyclic dynamics (i.e. wave and tidal regime, sediment budget with the recurrence of regression and accretion phases), is associated with visible modifications in both plant communities and landscape, so that this sound relationship can be used as a monitoring tool in coastal areas (Araùjo et al., 2002). Particularly plant communities, that represent well-identifiable land elements with a relatively stable composition, structure and mutual relationships, all related to specific environmental conditions, can provide reliable monitoring activities (Loidi, 1994; Lomba et al., 2008).

At present, plant communities zonation along the $\mathrm{N}$-Adriatic coast is complete only at few sites, mostly located at some distance from areas of urban development, where tourism is limited by legislation (Porto Caleri) or simply because of the difficulty in reaching them (i.e., $\mathrm{Ca}^{\prime}$ Roman and the Tagliamento mouth). In almost all the rest of the Veneto coast, actual vegetation zonation is noticeably far from the potential one. Where disturbance events were very strong, some PNV communities completely disappeared and available space has been occupied by replacement ruderal communities.

The worst conservation status has been found on the central part of Venetian coastline, affected by urbanization, agriculture as well as heavy tourist presence, and here the natural landscape appears much more endangered in terms of trampling and alien invasions linked to human settlements and in some portion it has completely disappeared.

Factors causing the disturbance are of various types and act at multiple temporal and spatial scales, translating into effects that manifest themselves differently in space and time. 
Moreover, it can be very difficult to distinguish actual sources of impact and to separate their individual effects (e.g., human trampling vs. erosion or embankment removing foredunes) (Defeo et al., 2009), or to find unaltered and natural beaches that could act as good control sites.

In Veneto region, most of the coastline is increasingly deprived of sand since groynes, jetties and revetments trap sediments that would otherwise supply beaches; activities such as land reclamation, urbanisation, afforestation and agricultural use further interfere with the sediment budget (Nordstrom, 2000). As a result, nearly $50 \%$ of the Venetian beaches are experiencing erosion (Bondesan \& Meneghel, 2004), which mostly impacts beaches and embryonic dunes. Human's response to beach erosion and retreat has historically consisted in placing armouring structures (Charlier et al., 2005), that alter the natural hydrodynamic system of waves and currents, modifying sand transport rates, which in turn affect the erosion/accretion dynamics (Miles et al., 2001), possibly causing further deep habitat changes.

Particularly embryonic dunes are landfoms strongly related to beach dynamics and can thus be regarded as effective geo-indicators of coastal evolution. Absence of embryonic dunes is typical of coastal areas suffering from erosion phenomena which can be recognized through geomorphologic features, but as eroding beaches become narrower, the reduced surface directly reduce diversity of ecosystems, particularly in the upper intertidal zone (Dugan et al., 2008). Coastal erosion can thus lead to structural modifications in terms of denudation of some sites, thus truncating the coastal sequence completely removing the first terms (i.e., Cakile maritima and Elymus farctus communities) or drastically reducing their space thus causing communities merge together. Geomorphic events in mobile dunes even induce severe changes on inland areas as the defensive physical barrier provided by mobile dunes weakens. Disruptions of mobile dunes promote erosional gaps on the fixed dunes and a decline in vigour of Ammophila arenaria. As its resilience declines, marram is joined by more species, first by other specialised dune plants, then by less specialised grasses, droughttolerant annuals such as those of Sileno-Vulpietum, a community rich in ruderal taxa.

Erosion is probably responsible for the small number of beaches and mobile dunes patches in NLF, but human pressures, mainly through trampling and beach grooming, can also promote the disruption of embryonic and foredunes, thus acting in synergy with erosion. As already pointed out by several studies (Brown \& McLachlan, 2002; Carboni et al., 2009; Grunewald \& Schubert, 2007; Kutiel et al., 1999; but see also Bonte \& Hoffmann, 2005 for further references), trampling and other recreation-bound human activities, such as beach cleaning are among the most severe factors impacting sandy shores resulting in fragmentation, communities merging and/or replacement, alien invasion and in an overall lowering of diversity values. In SLF, where beaches are mainly in accretion phase, human disturbance is particularly intense and beach communities have almost completely disappeared from many sites, substituted by ruderal replacement communities.

Strong accumulation of mobile sand in interior areas has severe consequences also on plant communities of grey dunes, which in connection with trampling, causes the occurrence of plant species that are normally typical of embryonic dunes and a decrease in number of 
character species. Within the edapho-xerophilous series, grey dunes (Tortulo-Scabiosetum) show the highest amount of alien species, both exotic and human-favoured ruderal species. Particularly dwarf shrubs, which represent the most typical component, seem to be the least tolerant plants relative to trampling (Cole, 1995).

While pioneer stages mainly suffer from coastal erosion and tourism, at the other extreme, fixed dune communities are affected mostly by urbanization. As erosion and tourism pressures truncate the first elements of the zonation, towns and villages, coastal roads, pines plantations and agriculture truncate the last stages of the typical zonation. Human disturbance on intermediate shrub communities is chiefly represented by urban development, campsites, leisure facilities, roads and afforestation, while urban development and cultivated land have drastically reduced the area covered by holm-oak woods and at present well-preserved woods survive at only very few coastal sites. The effects of disturbance on coastal dune ecosystem vary according to the severity of the disturbance, but on fixed dunes and dune slacks transition disturbance usually drives to the complete disappearance of natural communities.

Therefore, the primary long-term threat coastal sandy ecosystems are facing is a "coastal squeeze" (Defeo et al., 2009; Schlacher et al., 2007), which causes sandy systems to be trapped between erosion on the sea side and human settlements inlands, thus leaving no space for natural sediment dynamics.

The two nested levels of analysis, considering higher organization level, the landscape level (with both composition and structure evaluation) as well as lower level (community level), such as species diversity and vegetation quality, provided a mutual description and evaluation of the naturalness of coastal landscape in the two coastal sectors studied and a sound assessment of their conservation status.

Coastal sand dune landscapes hold habitats of high economic, social and ecological value on a worldwide scale. At the same time, they are among the most threatened ecosystems on a national and European scale, facing escalating anthropogenic pressures. Sand dune habitat loss and degradation is leading to a remarkable biodiversity loss, which in turn can result in irreversible damage to ecosystem functions and ecological services. While some existing geo-physical models can be applied to predict climate-related changes for coastal areas (Zhang et al., 2004), no equivalents exist for the ecological effects of global change which could lead to a significant net loss of dune areas over the next century. Because of the scale of the problem, interdisciplinary and innovative approaches are required and the continued existence of sandy coastal areas as functional ecosystems is likely to depend on direct conservation efforts, which will have to progressively incorporate ecological aspects of coastal landscapes (Schlacher et al., 2007).

The most recent European legislation, in particular the Marine Strategy Framework Directive, which encompasses and reinforces other previous EU Directives such as WFD 2000/60 and Habitat Directive 92/43, calls for a strategic approach to coastal zone management providing sustainable development. The integrated and ecosystem-based approach used in this paper fulfils most EU requirements for policy making and by dealing with the problem both 
through a community-oriented and a landscape pattern-oriented approach it can provide a comprehensive framework for sustainable coastal management and development and for the improvement of projects or actions supporting biodiversity and ecosystem services. This approach could thus represent an innovative tool for the sustainable management assessment as it provides clear and easy applicable monitoring instruments allowing planners and stakeholders to evaluate the effectiveness of different action plans. Provided a solid classification, plant community types can be considered highly reliable indicators of environmental status in coastal areas. Moreover, the hierarchical landscape classification, coupled with the PNV concept, results in a reference model for environmental monitoring of anthropogenic pressures on coastal areas, providing interconnected spatial units which help dealing with the complex and dynamic nature of ecosystems.

\section{Author details}

Gabriella Buffa, Edy Fantinato and Leonardo Pizzo

DAIS - Dept. of Environmental Sciences, Informatics and Statistics, $\mathrm{Ca}^{\prime}$ Foscari University, Italy

\section{References}

Acosta, A.; Blasi, C. \& Stanisci, A. (2000). Spatial connectivity and boundary patterns in coastal dune vegetation in the Circeo National Park, Central Italy. Journal of Vegetation Science, Vol. 11, pp. 149-154.

Acosta, A.; Blasi, C.; Carranza, M.L.; Ricotta, C. \& Stanisci, A. (2003b). Quantifying ecological mosaic connectivity and hemeroby with a new topoecological index. Phytocoenologia, Vol. 33, pp. 623-631.

Acosta, A.; Stanisci, A.; Ercole, S. \& Blasi, C. (2003a). Sandy coastal landscape of the Lazio region (Central Italy). Phytocoenologia, Vol. 33, pp. 715-726.

Acosta, A.; Carranza, M. L. \& Giancola, M. (2005). Landscape change and ecosystem classification in a municipal district of a small city (Isernia, Central Italy). Environmental Monitoring and Assessment, Vol. 108, pp. 323-335.

Acosta, A.; Ercole, S.; Stanisci, A.; De Patta Pillar, V. \& Blasi, C. (2007). Coastal Vegetation Zonation and Dune Morphology in Some Mediterranean Ecosystems. Journal of Coastal Research, Vol. 23, pp. 1518-1524.

Akcakaya, H.R.; Ferson, S.; Burgman, M.A.; Keith, D.A.; Mace, G.M. \& Todd, C. (2000). Making consistent IUCN classifications under uncertainty. Conservation Biology, Vol. 14, pp. 1001-1013.

Allen, T.F.H. \& Starr, T.B. (1982). Hierarchy: perspectives for ecological complexity, University of Chicago Press, Chicago.

Araújo, R.; Honrado, J.; Granja, H.M.; De Pinho, S.N. \& Caldas, F.B. (2002). Vegetation complexes of coastal sand dunes as an evaluation instrument of geomorphologic changes in the coastline, In: Littoral 2002. The Changing Coast. EUROCOAST/EUCC, pp. 337-339, Porto, Portugal. 
Barbier, E.B.; Koch, E.W.; Silliman, B.R.; Hacker, S.D.; Wolanski, E.; Primavera, J.; Granek, E.F.; Polasky, S; Aswani, S.; Cramer, L.A.; Stoms, D.M.; Kennedy, C.J.; Bael, D.; Kappel, C.V.; Perillo, G.M.E.; Reed, D.J. (2008). Coastal Ecosystem-Based Management with Nonlinear Ecological Functions and Values. Science, Vol. 319, pp. 321-323.

Barbour, M.G. (1992). Life at the leading edge: The beach plant syndrome, In: Coastal plant communities of Latin America, Seeliger U. (Ed.), pp. 291-307, Academic, San Diego.

Bezzi, A. \& Fontolan, G. (2003). Foredune classification and morphodynamic processes along the Veneto coast (N. Adriatic, Italy), In: MEDCOAST '03, Özhan, E. (Ed.), pp 1425-1434, MEDCOAST Secretariat, Ankara.

Bezzi, A.; Fontolan, G.; Nordstrom, K.F.; Carrer, D. \& Jackson, N.L. (2009). Beach nourishment and foredune restoration: practices and constraints along the Venetian shoreline, Italy. Journal of Coastal Research, Vol. 56, pp. 287-291.

Bini, C.; Buffa, G.; Gamper, U.; Sburlino, G. \& Zilocchi, L. (2002). Soils and vegetation of coastal and wetland areas in Northern Adriatic (NE Italy). 7th Int. Meet. Soils with Mediterranean Type Climate (Selected Papers), Options Méditerranéènnes, Ser. A, Vol. 50, pp. 31-36.

Biondi, E. (1994). The phytosociological approach to landscape study. Ann. Bot., Vol. 52, pp. 135-141.

Biondi E. (1999). Diversità fitocenotica degli ambienti costieri italiani, In: Aspetti ecologici e naturalistici dei sistemi lagunari e costieri, Bon, M.; Sburlino, G. \& Zuccarello, V. (Eds.), pp. 39-105, Arsenale Editrice, Venezia.

Biondi, E. (2011). Phytosociology today: Methodological and conceptual evolution. Plant Biosystems, Vol. 145, no. 1, pp. 19-29.

Blasi, C.; Carranza, M.L.; Frondoni, R. \& Rosati, L. (2000). Ecosystem classification and mapping: A proposal for Italian landscapes. Applied Vegetation Science, Vol. 3, pp. 233242.

Blasi, C.; Filibeck, G.; Frondoni, R.; Rosati, L. \& Smiraglia, D. (2004). The map of the vegetation series of Italy. Fitosociologia, Vol. 41, no. 1 Suppl. 1, pp. 21-25.

Blasi, C.; Capotorti, G.; Frondoni, R. (2005). Defining and mapping typological models at the landscape scale. Plant Biosystems, Vol. 139, pp. 155-163.

Blasi, C. \& Frondoni, R. (2011). Modern perspectives for plant sociology: The case of ecological land classification and the ecoregions of Italy. Plant Biosystems, Vol. 145, pp. 30-37.

Bondesan, A. \& Meneghel, M. (Eds.). (2004). Geomorfologia della provincia di Venezia, Esedra Editrice, Padova.

Bondesan, A.; Primon, S.; Bassan, V. \& Vitturi, A. (Eds.). (2008). Le unità geologiche della provincia di Venezia, Provincia di Venezia, Università di Padova, Venezia.

Bonn, A. \& Gaston, K.J. (2005). Capturing biodiversity: selecting high priority areas for conservation using different criteria. Biodivers. Conserv., Vol. 14, pp. 1083-1100.

Bonte, D. \& Hoffmann, M. (2005). Are coastal dune management actions for biodiversity restoration and conservation underpinned by internationally published scientific research?, In: Dunes and Estuaries 2005, Herrier, J.-L.; Mees, J.; Salman, A.; Seys, J.; Van Nieuwenhuyse H. \& Dobbelaere I. (Eds.), pp. 165-178, Proceedings International 
Conference on Nature Restoration Practices in European Coastal Habitats, Koksijde, Belgium, 19-23 September 2005.

Braun-Blanquet, J. (1964). Pflanzensoziologie. 3rd edn. Springer, Wien.

Brown, A.C. \& McLachlan, A. (2002). Sandy shore ecosystems and the threats facing them: some predictions for the year 2025. Environ. Conserv., Vol. 29, pp. 62-77.

Buffa, G.; Mion, D.; Gamper, U.; Ghirelli, L. \& Sburlino, G. (2005). Valutazione della qualità e dello stato di conservazione degli ambienti litoranei: l'esempio del S.I.C. "Penisola del Cavallino: biotopi litoranei" (Venezia, NE-Italia). Fitosociologia, Vol. 42, pp. 3-13.

Buffa, G.; Filesi, L.; Gamper, U. \& Sburlino, G. (2007). Qualità e grado di conservazione del paesaggio vegetale del litorale sabbioso del Veneto (Italia settentrionale). Fitosociologia, Vol. 44, pp. 49-58.

Buffa, G. \& Lasen, C. (2010). Atlante dei siti Natura 2000 del Veneto, Regione del Veneto Direzione Pianificazione Territoriale e Parchi, Venezia.

Buffa, G. \& Villani, C. (2012). Are the ancient forests of the Eastern Po plain large enough for a long-term conservation oh herbaceous nemoral species? Plant Biosystems, in press.

Cadenasso, M.L. \& Pickett, S.T.A. (2001). Effect of edge structure on the flux of species into forest interiors. Conservation Biology, Vol. 15, pp. 91-97.

Carboni, M.; Carranza, M.L. \& Acosta, A. (2009). Assessing conservation status on coastal dunes: A multiscale approach. Landscape and Urban Planning, Vol. 91, pp. 17-25

Carranza, M.L.; Acosta, A.T.R.; Stanisci, A.; Pirone, G. \& Ciaschetti, G. (2008). Ecosystem classification for EU habitat distribution assessment in sandy coastal environments: An application in central Italy. Environ. Monit. Assess., Vol. 140, pp. 99-107.

Chapman, V. J. (1976). Coastal Vegetation (2nd Ed.), Pergamon Press, Oxford.

Charlier, R.H.; Chaineux, M.C.P. \& Morcos, S. (2005). Panorama of the history of coastal protection. Journal of Coastal Research, Vol. 21, pp. 79-111.

Chiaudani, A. (2008). Agroclimatologia statica e dinamica del Veneto. Analisi del periodo 19562004, Tesi di Dottorato di Ricerca in Scienze delle Produzioni Vegetali, indirizzo Agronomia Ambientale, Università degli Studi di Padova, Padova.

Cingolani, A.M.; Vaieretti, M.V.; Gurvich, D.E.; Giorgis, M.A. \& Cabido, M. (2010). Predicting alpha, beta and gamma plant diversity from physiognomic and physical indicators as a tool for ecosystem monitoring. Biological Conservation, Vol. 143, pp. 25702577.

Cole, D.N. (1995). Experimental trampling of vegetation. II. Predictors of resistance and resilience. Journal of Applied Ecology, Vol. 32, pp. 215-224.

Curr, R.H.F.; Koh, A.; Edwards, E.; Williams, A.T. \& Daves, P. (2000). Assessing anthropogenic impact on Mediterranean sand dunes from aerial digital photography. Journal of Coastal Conservation, Vol. 6, pp. 15-22.

Dal Cin, R. \& Simeoni, U. (1994). A model for determining the classification, vulnerability and risk in the Southern coastal zone of the Marche (Italy). Journal of Coastal Research, Vol. 10, pp. 18-29.

Davenport, J. \& Davenport, J.L. (2006). The impact of tourism and personal leisure transport on coastal environments: a review. Estuarine, Coastal and Shelf Science, Vol. 67, pp. 280292. 
Defeo, O.; McLachlan, A.; Schoeman, D.S.; Schlacher, T.A.; Dugan, J.; Jones, A.; Lastra, M. \& Scapini, F. (2009). Threats to sandy beach ecosystems: A review. Estuarine, Coastal and Shelf Science, Vol. 81, pp. 1-12.

Dugan, J.E. \& Hubbard, D.M. (2010). Loss of Coastal Strand Habitat in Southern California: The Role of Beach Grooming. Estuaries and Coasts, Vol. 33, pp. 67-77.

Dugan, J.E.; Hubbard, D.M.; Rodil, I.; Revell, D.L. \& Schroeter, S. (2008). Ecological effects of coastal armoring on sandy beaches. Marine Ecology, Vol. 29, pp. 160-170.

EEA (1995). Europe's environment: the Dobrís assessment, EEA, Copenhagen.

EEA (1999). State and pressures of the marine and coastal Mediterranean environment, E. Papathanassiou \& G. P. Gabrielidis (Eds.), European Environment Agency, Environmental assessment series No. 5, Available from http://reports.eea.eu.int/ENVSERIES05/en/envissue05.pdf

E.C., DG XXIII (1998). Fact and figures on the Europeans on holiday 1997-98, Eurobarometer, no. 48 , Brussels.

ESRI (2008). ArcGIS 9.3, Environmental Systems Research Institute, Redlands, California.

Feola, S.; Carranza, M.L.; Schaminée, J.H.J.; Janssen, J.A.M. \& Acosta, A.T.R. (2011). EU habitats of interest: an insight into Atlantic and Mediterranean beach and foredunes. Biodivers. Conserv., Vol. 20, pp. 1457-1468.

Fernández-González, F.; Loidi, J. \& Moreno Sainz, J.C. (2005). Impacts on plant biodiversity, In: Evaluación preliminar de los impactos en España por efecto del cambio climático, Moreno J.M. (ed.), pp. 183-247, Ministerio de Medio Ambiente, Madrid.

Forman, R.T.T. (1995). Land mosaics: the ecology of landscapes and regions, Cambridge University Press, New York.

Forman, R.T.T. (1996). Land Mosaic, Cambridge University Press, Cambridge.

Forman, R. \& Godron, M. (1986). Landscape ecology, Wiley \& Sons, New York.

Franklin, J.F.; Cromack, K.; Denison, W.; McKee, A.; Maser, C.; Sedell, J.; Swanson, F. \& Juday, G. (1981). Ecological characteristics of old-growth Douglas-fir forests, USDA Forest Service General Technical Report PNW-1, 18, Pacific Northwest Forest and Range Experiment Station, Portland, Oregon.

Frederiksen, L.; Kollmann, J.; Vestergaard, P. \& Bruun, H.H. (2006). A multivariate approach to plant community distribution in the coastal dune zonation of NW Denmark. Phytocoenologia, Vol. 36, pp. 321-342.

Gamper, U. (2002). Caratteristiche ecologiche della vegetazione a carattere mediterraneo presente sul litorale sedimentario nord-adriatico (Veneto-NE-Italia), con particolare riguardo alle problematiche di conservazione della biodiversità fitocenotica, Tesi di Dottorato in "Biologia ed ecologia vegetale in ambiente mediterraneo", Università di Catania.

Gamper, U.; Filesi, L.; Buffa, G. \& Sburlino, G. (2008). Diversità fitocenotica delle dune costiere nord-adriatiche 1 - le comunità fanerofitiche. Fitosociologia, Vol. 45, pp. 3-21.

Garbari, F. (1984). Aspetti della flora e della vegetazione delle nostre coste marine. Agricoltura Ambiente, Vol. 23, pp. 45-48.

Géhu, J.M. \& Géhu, J. (1980). A methodology for the objective evaluation of natural environments. Coastal examples, Third Seminary of Applied Phytosociology "Biological Evaluation of the Territory through Biocenotic Indices", Institute Européen d'Ecologie, Metz, pp. 75-94. 
Géhu , J.M.; Scoppola, A.; Caniglia, G.; Marchiori, S. \& Gehu-Franck, J. (1984). Les systèmes végétaux de la còte nord-adriatique italienne. Leur originalité à l'échelle européenne. Doc. Phytosoc., N.S. Vol. 8, pp. 486-558.

Géhu, J.M. \& Biondi, E. (1994). Anthropization of Mediterranean dunes, In: Alterazioni Ambientali ed Effetti sulle Piante, Ferrari, C.; Manes, F. \& Biondi, E. (Eds.), pp. 160-176, Edagricole, Bologna.

Grime, J.P. (2002). Plant Strategies, Vegetation Processes, and Ecosystem Properties, Wiley \& Sons, Chichester.

Grunewald, R. \& Schubert, H. (2007). The definition of a new plant diversity index " $\mathrm{H}^{\prime}$ dune" for assessing human damage on coastal dunes-Derived from the Shannon index of entropy $\mathrm{H}^{\prime}$. Ecological Indicators, Vol. 7, pp. 1-21.

Gustafson, E. J. (1998). Quantifying Landscape Spatial Pattern: What Is the State of the Art? Ecosystems, Vol. 1, no. 2, pp. 143-156.

Hermy, M. \& Cornelis, J. (2000). Towards a monitoring method and a number of multifaceted and hierarchical biodiversity indicators for urban and suburban parks. Landsc. Urban Plan., Vol. 49, pp. 149-162.

IUCN, (2006). Guidelines for Using the IUCN Red List Categories and Criteria. Version 6.2. Prepared by the Standards and Petitions Working Group of the IUCN SSC Biodiversity Assessments Sub-Committee in December 2006. Available from http://app.iucn.org/webfiles/doc/SSC/RedList/RedListGuidelines.pdf

Klijn, F., \& Udo de Haes, H.A. (1994). A hierarchical approach to ecosystems and its implications for ecological land classification. Landscape Ecology, Vol. 9, pp. 89-104.

Kutiel, P.; Peled, Y. \& Geffen, E. (2000). The effect of removing scrub cover on annual plants and small mammals in a coastal sand dune ecosystem. Biological Conservation, Vol. 94, pp. 235-242.

Levin, S.A. (1992). The problem of pattern and scale in ecology. Ecology, Vol. 73, pp. 19431967.

Loidi, J. (1994). Phytosociology applied to nature conservation and land management. In: Song, Y.; Dierschke, H. \& Wang, X. (Eds.), Proceed. 36th IAVS Symp. in Shanghai, East China Normal Univ. Press.

Lomba, A.; Alves, P. \& Honrado, J. (2008). Endemic Sand Dune Vegetation of the Northwest Iberian Peninsula: Diversity, Dynamics, and Significance for Bioindication and Monitoring of Coastal Landscapes. Journal of Coastal Research, Vol. 24, no. 213 (Supplement 20), pp. 113-121.

Lopez, R.D. \& Fennessy, M.S. (2002). Testing the floristic quality assessment index as an indicator of wetland condition. Ecol. Appl., Vol. 12, pp. 487-497.

Lorenzoni, G.G. (1983). Il paesaggio vegetale nord Adriatico. Atti Mus. civ. St. nat. Trieste, Vol. 35, pp. 1-34.

Lortie, C.J. \& Cushman, J.H. (2007). Effects of a directional abiotic gradient on plant community dynamics and invasion in a coastal dune system. Journal of Ecology, Vol. 95, pp. $468-481$.

Margules, C.R. \& Pressey, R.L. (2000). Systematic conservation planning. Nature, Vol. 405, pp. 243-252. 
Martínez, M.L.; Psuty, N.P. \& Lubke, R.A. (2004). A perspective on coastal dunes, In: Coastal dunes. Ecology and Conservation, Martínez, M.L. \& Psuty, N.P. (Eds.), pp. 3-10, Ecological Studies, Vol. 171, Springer, Berlin.

Matson, B.E., \& Power, R.G. (1996). Developing an ecological land classification for the Fundy Model Forest, south-eastern New Brunswick, Canada. Environmental Monitoring and Assessment, Vol. 39, pp. 149-172.

McGarigal, K. \& Marks, B.J. (1995). FRAGSTATS: spatial analysis program for quantifying landscape structure. USDA Forest Service General Technical Report PNW-GTR-351, USDA, Washington DC.

McKinney, M.L. (2002). Urbanization, biodiversity, and conservation. BioScience, Vol. 52, pp. 883-890.

McLeod, K.; Lubchenco, J.; Palumbi, S. \& Rosenberg, A. (2005). Scientific Consensus Statement on Marine Ecosystem-Based Management, Communication Partnership for Science and the Sea, 2005; Available from http://compassonline.org/marinescience/solutions_ecosystem.asp

Miles, J.R.; Russell, P.E. \& Huntley, D.A. (2001). Field measurements of sediment dynamics in front of a seawall. Journal of Coastal Research, Vol. 17, pp. 195-206.

Mücher, C.A.; Bunce, R.G.H.; Hennekens, S.M. \& Shaminée, J.H.J. (2004). Mapping European habitat to support the design and implementation of a pan-European network: the PEENHAB project, Alterra report 952, Wageningen.

Nordstrom, K.F. (2000). Beaches and Dunes on Developed Coasts. Cambridge University Press, Cambridge, pp. 338.

Nordstrom, K. F.; Gamper, U.; Fontolan, G.; Bezzi, A. \& Jackson, N.L. (2009). Characteristics of Coastal Dune Topography and Vegetation in Environments Recently Modified Using Beach Fill and Vegetation Plantings, Veneto, Italy. Environmental Management, Vol. 44, pp. 1121-1135.

Noss, R.F. 1990. Indicators for monitoring biodiversity: a hierarchical approach. Conservation Biology, Vol. 4, pp. 355-364.

O'Neill, R.V.; DeAngelis, D.L.; Allen, T.F.H. \& Waide, J.B. (1986). A hierarchical concept of ecosystems. Monographs in Population Biology, 23, Princeton University Press, Princeton.

O'Neill, R.V.; Johnson, A. R. \& King, A.W. (1989). A hierarchical framework for the analysis of scale. Landscape Ecology, 3: 193-205.

Patton, D.R. (1975). A diversity index for quantifying habitat edge. Wildl. Soc. Bull., Vol. 3, pp. 171-173.

Pignatti, S. (1959). Ricerche sull'ecologia e sul popolamento delle dune del litorale di Venezia. Il popolamento vegetale. Boll. Mus. Civ. Venezia, Vol. 12, pp. 61-142.

Pignatti, S. (2009). Com'è triste Venezia, soltanto mezzo secolo dopo. Parchi, Vol. 58, pp. 5970.

Poldini, L.; Vidali, M. \& Fabiani, M.L. (1999). La vegetazione del litorale sedimentario del Friuli-Venezia Giulia (NE Italia) con riferimenti alla regione alto-Adriatica. Studia Geobotanica, Vol. 17, pp. 3-68.

Polli, S. (1970). Tabelle di previsione delle maree per Trieste e l'Adriatico Settentrionale per l'anno 1971. Istituto Talassografico Sperimentale Trieste, Trieste, pp. 20. 
Ragazzi, F.; Vinci, I.; Garlato, A.; Giandon, P. \& Mozzi P. (Eds.) (2005). Carta dei suoli del bacino scolante in laguna di Venezia. ARPAV Osservatorio Regionale Suolo, Castelfranco Veneto, pp. 399.

Ragazzi, F. \& Zamarchi, P. (Eds.) (2008). I suoli della provincia di Venezia. Servizio Geologico e Difesa del Suolo della Provincia di Venezia, ARPAV Osservatorio Regionale Suolo, Castelfranco Veneto, pp. 268.

Ranwell, D. (1972). Ecology of Salt Marshes and Sand Dunes. Chapman and Hall, London, pp.258.

Rescia, A.J.; Schmitz, M.F.; Martín de Agar, P.; de Pablo, C.L. \& Pineda, F.D. (1997). A fragmented landscape in northern Spain analyzed at different spatial scales: implications for management. J. Veg. Sci., Vol. 8, pp. 343-352.

Richardson, D.M.; Pyšek, P.; Rejmánek, M.; Barbour, M.G.; Panetta, D.F. \& West C.J. (2000). Naturalization and invasion of alien plants: concepts and definitions. Diversity and Distributions, Vol. 6, pp. 93-107.

Rivas-Martinez, S. (2008). Global bioclimatics (Clasificación bioclimatica de la Tierra). Version 1/12/2008. Available from http://www.globalbioclimatics.org

Rodgers, J.C. (2002). Effects of human disturbance on the dune vegetation of the Georgia Sea Islands. Phys. Geogr., Vol. 23, no. 1, pp. 79-94.

Rodgers, J.C. \& Parker, K.C. (2003). Distribution of alien plant species in relation to human disturbance on the Georgia Sea Islands. Diversity and Distributions, Vol. 9, no. 5, pp. 385398.

Rowe, J.S. (1996). Land classification and ecosystem classification. Environmental Monitoring and Assessment, Vol. 39, pp. 11-20.

Sala, O.E.; Chapin, F.S. III; Armesto, J.J.; Berlow, E.; Bloomfield, J.; Dirzo, R.; HuberSanwald, E.; Huenneke, L.F.; Jackson, R.B.; Kinzig, A.; Leemans, R.; Lodge, D.M.; Mooney, H.A.; Oesterheld, M.; Poff, N.L.; Sykes, M.T.; Walker, B.H.; Walker, M. \& Wall D.H. (2000). Global biodiversity scenarios for the year 2100. Science, Vol. 287, pp. 17701774 .

Sax, D.F. \& Gaines, S.D. (2003). Species diversity: from global decrease to local increase. Trends in Ecology and Evolution, Vol. 18, pp. 561-566.

Sburlino, G.; Buffa, G.; Filesi, L. \& Gamper U. (2008). Phytocoenotic originality of the NAdriatic coastal sand dunes (Northern Italy) in the European context: The Stipa venetarich communities. Plant Biosystems, Vol. 142, pp. 533-539.

Schlacher, T.A.; Dugan, J.; Schoeman, D.S.; Lastra, M.; Jones, A.; Scapini, F.; McLachlan, A. \& Defeo, O. (2007). Sandy beaches at the brink. Diversity and Distributions, Vol. 13, pp. 556560.

Schlacher, T.A.; Schoeman, D.S.; Dugan, J.; Lastra, M.; Jones, A.; Scapini, F. \& McLachlan A. (2008). Sandy beach ecosystems: Key features, management challenges, climate change impacts, and sampling issues. Marine Ecology, Vol. 29, pp. 70-90.

Seabloom, E.W. \& Wiedemann, A.M. (1994). Distribution and effects of Ammophila breviligulata Fern. (American beachgrass) on the foredunes of the Washington coast. Journal of Coastal Research, Vol. 10, pp. 178-188. 
Sims, R.A.; Corns, I.G.W. \& Klinka, K. (1996). Global to local: Ecological land classification Introduction. Environ. Monitor. Assessment, Vol. 39, pp. 1-10.

Sokal, R.R. \& Rohlf, F.J. (1995). Biometry.W.H. Freeman, New York.

Stanisci, A.; Feola, S. \& Blasi, C. (2005). Map of vegetation series of Ponza island (central Italy). Lazaroa, Vol. 26, pp. 93-113.

Sykes, M.T. \& Wilson, J.B. (1991). Vegetation of a coastal sand dune system in southern New Zealand. J. Veg. Sci., Vol. 2, pp. 531-538.

Tüxen, R. (1956). Die heutige potentielle natürliche Vegetation als Gegenstand der Vegetationskartierung. Angewandte Pflanzensoziologie (Stolzenau), Vol. 13, pp. 5-42.

UNCED (1992). United Nations Conference on Environment and Development, Agenda 21, Chapter 17: Protection of the Oceans, All Kinds of Seas, Including Enclosed and Semi-Enclosed Seas, and Coastal Areas and the Protection, Rational Use and Development of Their Living Resources. United Nations Divison for Sustainable Development, New York, pp. 42.

van der Maarel, E. (2003). Some remarks on the functions of European coastal ecosystems. Phytocoenologia, Vol. 33, pp. 187-202.

Werner, P.C.; Gerstengarbe, F.W.; Friedrich, K. \& Oesterle, H. (2000). Recent climate change in the North Atlantic/European Sector. Int. Journal of Climatology, Vol. 20, no. 5, pp. 463471.

Westhoff, V. \& van der Maarel, E. (1973). The Braun-Blanquet approach. In: Ordination and classification of communities, Whittaker, R.H. (Ed.), pp. 617-726, Handbook of vegetation science, Vol. 5, Junk, The Hague.

Wilson, B. \& Sykes, M.T. (1999). Is zonation on coastal sand dunes determined primarily by sand burial or salt spray? A test in New Zealand dunes. Ecol. Lett., Vol. 2, pp. 233-236.

Zhang, K.Q.; Douglas, B.C. \& Leatherman, S.P. (2004). Global warming and coastal erosion. Climate Change, Vol. 64, pp. 41-58.

Zonneveld, I. S. (1995). Land ecology: An introduction to landscape ecology as a base for land evaluation, land management and conservation, SPB Academic Publishing, Amsterdam.

Zunica, M. (Ed.) (1971). Evoluzione dei litorali dal Tagliamento all'Adige con particolare riguardo ai lidi della Laguna di Venezia (Relazione definitiva). Min. Lav. Pubbl. Com. St. Provv. Venezia, Padova. 